\title{
Effect of aseismic ridge subduction on slab geometry and overriding plate deformation: Insights from analogue modeling
}

\author{
Joseph Martinod $^{1}$, Benjamin Guillaume ${ }^{2,3}$, Nicolas Espurt ${ }^{4}$, Claudio Faccenna ${ }^{5}$, Francesca \\ Funiciello $^{5}$ and Vincent Regard ${ }^{1}$ \\ ${ }^{1}$ Géosciences Environnement Toulouse, UMR CNRS-IRD-Université de Toulouse, 14 av. E. \\ Belin, F-31400, Toulouse, France \\ ${ }^{2}$ Géosciences Rennes, UMR 6118, Université de Rennes1, Rennes, France \\ ${ }^{3}$ Laboratoire de Planétologie et Géodynamique, UMR 6112, Université de Nantes, Nantes, \\ France \\ ${ }^{4}$ CEREGE-CNRS-Université Aix-Marseille III, Aix-en-Provence, France \\ ${ }^{5}$ Laboratory of Experimental Tectonics, Dipartamento di Scienze Geologiche, Università \\ degli studi Roma TRE, Roma, Italy
}

\begin{abstract}
We present analogue models simulating the subduction of a buoyant ridge oriented perpendicularly or obliquely with respect to the trench, beneath an advancing overriding plate. The convergence velocity is imposed by lateral boundary conditions in this experimental set. We analyze the three-dimensional geometry of the slab, the deformation and topography of the overriding plate. Experiments suggest that ridge subduction diminishes the dip of the slab, eventually leading to the appearance of a horizontal slab segment in case boundary conditions impose a rapid convergence. This result contrasts with that obtained in free subduction experiments, in which ridge subduction diminishes the convergence velocity which, in turn, increases the dip of the slab beneath the ridge. The slab dip decrease is accompanied by the indentation of the overriding plate by the ridge, resulting in arc curvature. Experiments suggest that indentation is larger for small convergence velocity and large slab dip. Ridge subduction also uplifts the overriding plate. Uplift first occurs close to the trench ( $\sim$ fore-arc area) and is accompanied by the flexural subsidence of the overriding plate behind the uplifted area ( back-arc subsidence). The uplifted area migrates within the overriding plate interiors following the appearance of a horizontal slab segment. These results are compared with natural examples of ridge subduction in the circum-Pacific area. They explain why ridge subduction may have contrasted effects on the overriding plate dynamics depending on the global conditions that constrain the converging system.
\end{abstract}

\section{Introduction}

The subduction of high bathymetric reliefs located within oceanic plates (aseismic ridges or oceanic plateaus) has been linked with several changes in the geometry and kinematics of both the subducting and overriding plates. This observation has been made on many natural examples since the beginnings of plate tectonics theory (e.g., Vogt, 1973; Vogt et al., 1976; Cross and Pilger, 1982; McCann and Habermann, 1989). Authors show that aseismic ridges forced into subduction often result in (1) a diminution of the slab dip (e.g., Pilger, 1981), (2) indentation of the overriding plate which, in turn, produces a cusp geometry of the trench and rotations/trench-perpendicular strike-slip faults within the overriding plate (Vogt, 1973; McCabe, 1984), (3) volcanic-arc segmentation and/or inhibition of arc volcanism (Nur and Ben-Avraham 1981; McGeary et al. 1985), (4) rapid uplift of the overriding plate in the fore-arc region (McCann and Habermann, 1989; Lallemand et al., 1992; Macharé and Ortlieb, 1992; Hampel, 2002) and in some cases far within the overriding plate interiors 
(Dumont, 1996; Ramos et al., 2002; Espurt et al., 2007; Regard et al., 2009), (5) back-arc deformation (Meffre and Crawford, 2001; Pardo et al., 2002), (6) aseismic behavior of the interplate contact area that may stop rupture propagation during major subduction earthquakes (seismic barrier, e.g., Melnick et al., 2009; Sparkes et al., 2010), and possibly in (7) a stronger interplate contact that may diminish the subduction velocity of the oceanic plate (Gutscher et al., 2000; Gutscher, 2002; Martinod et al., 2010). Recently, Rosenbaum and Mo (2011) revised the effects of ridge subduction in influencing both slab geometry and the tectonic and magmatic behaviors of the overriding plate, using examples from the circum-Pacific subduction zones. They show that although ridge subduction often modifies the dip of the slab, the upper plate tectonics and volcanism, these effects are not systematic. For instance, slab flattening is not observed in the western Pacific where the regional dip angle of the slab is steep, and the density of volcanoes is not always smaller above subducted ridges.

Several numerical and analogue models studying the effects of the subducting plate buoyancy either on the slab geometry, on the upper plate deformation, or on both the subducting and overriding plate dynamics have been recently published. The majority of published numerical models correspond to 2D-experiments that reproduce the subduction of a plateau or trench-parallel ridge beneath an overriding plate. These models look at changes in the dip of the slab resulting from different nature of the subducting plate as well as consequences on magmatism and upper plate topography (van Hunen et al., 2002; 2004; Gerya et al., 2009; Li et al., 2011). Mason et al. (2010) present 3D numerical models simulating the subduction of a trench-perpendicular buoyant ridge. Their models may be compared to analogue experiments presented in Martinod et al. (2005). In both papers, the subduction of trench-perpendicular buoyant ridges results in a diminution of the trench retreat velocity and in the appearance of an arched trench geometry that is convex towards the overriding plate. These 3D models, however, do not consider the effect of the overriding continent that may inhibit changes in the geometry of the trench. An attempt to fill this gap has been realized by Espurt et al. (2008) which studied the effects of a ridge parallel to the trench with application to the South American case. Here, we present a complete set of analogue models simulating the subduction of a buoyant ridge oriented perpendicularly or obliquely with respect to the trench. We analyze the effects of ridge subduction both on the slab geometry at depth and on the deformation and uplift of the overriding plate.

\section{Experimental set-up}

The experimental set-up adopted here is similar to that used by Espurt et al. (2008). We model the upper mantle using a low-viscosity glucose syrup. Syrup fills a rigid Plexiglas tank $\left(80 \mathrm{x} 80 \mathrm{x} 20 \mathrm{~cm}^{3}\right)$. The reference frame of these experiments is the box boundaries. It can be considered as the experimental analogue of the fixed hotspot reference frame. In most experiments, we model the subducting and overriding lithospheres using silicone plates whose density is calibrated to scale the buoyancy of natural plates (Tables 1 and 2). In the range of applied strain-rates, glucose syrup and silicone are Newtonian viscous materials in which stresses increase linearly with strain-rates (Funiciello et al., 2003). Indeed, tests performed with a rheometer (Physica MCR 301, Anton Paar) show that silicone viscosity is strain-rate independent for strain rates lower than $10^{-2} \mathrm{~s}^{-1}$. A rigid piston advancing at constant speed imposes the convergence velocity between plates (Figure 1). The glucose syrup is free to move underneath the piston. Some experiments have been performed without any overriding plate and piston, in order to understand the effects of the overriding plate on the process of subduction. In these "free subduction" experiments, the subducting plate simply sinks within the lowviscosity solution under its own weight, as in experiments presented in Funiciello et al. (2003) or Martinod et al. (2005). 


\begin{tabular}{lllll} 
Parameters & & Model & Nature \\
\hline $\mathbf{g}$ & Gravitational acceleration & $\mathbf{m ~ s}^{-2}$ & 9.81 & 9.81 \\
\hline $\begin{array}{l}\text { Thicknesses } \\
h\end{array}$ & Lithospheric plates & $\mathbf{m}$ & 0.013 & 86000 \\
$H$ & $\begin{array}{l}\text { Upper mantle } \\
\text { Length scale factor } L_{\text {model }} / L_{\text {nature }}=1.5 \times 10^{-7}\end{array}$ & 0.10 & 660000 \\
& & & \\
\hline
\end{tabular}

\section{Buoyancies}

$\Delta \rho_{\mathrm{o}}=\rho_{\mathrm{um}}-\rho_{\mathrm{o}}$

$\Delta \rho_{\mathrm{r}}=\rho_{\mathrm{um}}-\rho_{\mathrm{r}}$

$\Delta \rho_{\mathrm{u}}=\rho_{\mathrm{um}}-\rho_{\mathrm{u}}$

50 Ma-old oceanic lithosphere

kg m ${ }^{-3}$

$-80 \quad-35$

50 Ma-old ocean, $1900 \mathrm{~m}$ high ridge

Overriding lithosphere

$+40$

$+18$

Buoyancy scale factor $\Delta \rho_{\text {model }} / \Delta \rho_{\text {nature }}$

$=2.3$

\begin{tabular}{ll}
\hline Viscosities & \\
$\eta_{\mathrm{d}}$ & Oc Ma-old oceanic lithosphere \\
$\eta_{\mathrm{l}}$ & Oceanic plateau \\
$\eta_{\mathrm{u}}$ & Overriding lithosphere \\
$\eta_{\mathrm{um}}$ & Upper mantle \\
$\eta_{\mathrm{lm}}$ & Lower mantle \\
& Viscosity scale factor $\eta_{\text {model }} / \eta_{\text {nature }} \sim 3 \times 10^{-19}$
\end{tabular}

Pa s

$\begin{array}{ll}3.5 \times 10^{5} & \sim 10^{24} \\ 1.8 \times 10^{5} & \sim 10^{24} \\ 1.6 \times 10^{5} & \sim 10^{23} \\ 24 & \sim 10^{20} \\ \infty & \sim 10^{22}\end{array}$

\section{Characteristic time}

$\mathrm{t}:\left(\mathrm{t}_{\text {model }} / \mathrm{t}_{\text {nature }}\right)=$

$(\Delta \rho g L)_{\text {nature }} /(\Delta \rho g L)_{\text {model }} \cdot\left(\eta_{\text {model }} / \eta_{\text {nature }}\right)=8.7 \times 10^{-13}$

$\mathbf{s}$

28

$3.16 \times 10^{13}$

(28 s)

(1 Ma)

\section{Characteristic velocity}
$\mathrm{U}:\left(\mathrm{U}_{\text {model }} / \mathrm{U}_{\text {nature }}\right)=\left(\mathrm{t}_{\text {nature }} \cdot \mathrm{L}_{\text {model }}\right) /\left(\mathrm{t}_{\text {model }} \cdot \mathrm{L}_{\text {nature }}\right)=1.7 \times 10^{5}$
$\mathrm{m} \mathrm{s}^{-1}$
$3.3 \times 10^{-4}$
$1.9 \times 10^{-9}$
$\left(0.33 \mathrm{~mm} \mathrm{~s}^{-1}\right)$
$\left(6.0 \mathrm{~cm} \mathrm{a}^{-1}\right)$

Table 1: Scaling of parameters for the reference experiment (experiment 1)

In most experiments, we simulate the upper mantle-lower mantle discontinuity as an impermeable barrier (the bottom of the Plexiglas box; Table 2). The validity of this approximation has been confirmed by previous studies, which found that the direct penetration of the slab through the transition zone is inhibited if the timescale of the analyzed process is limited (order of few tens of Myrs) and if the viscosity increase at the upper-lower mantle boundary is at least one order of magnitude (Davies 1995; Guillou- Frottier et al. 1995; Christensen 1996; Funiciello et al. 2003). A more viscous syrup layer modeling part of the lower mantle has been introduced in some experiments. We observe that the presence of this layer does not modify significantly the results presented below. The lateral distance between the plate and box sides $\left(W_{\text {lat }}\right)$ is greater than the size of the advected cell within the upper mantle, which in first approximation corresponds to the thickness $H_{u m}$ of the advecting layer modeling the upper mantle (Figure 1). Then, the upper mantle easily flows around the slab edges in case the slab is moving with respect to the Plexiglas tank (Funiciello et al., 2004). 


\begin{tabular}{|c|c|c|c|c|c|c|c|c|c|c|c|c|c|c|c|c|}
\hline Experiment & 1 & 2 & 3 & 4 & 5 & 6 & 7 & 8 & 9 & 10 & 11 & 12 & 13 & 14 & 15 & 16 \\
\hline W (mm) & 300 & 300 & 300 & 300 & 300 & 300 & 300 & 300 & 300 & 300 & 300 & 300 & 300 & 300 & 300 & 300 \\
\hline Lo (mm) & 550 & 560 & 550 & 590 & 550 & 550 & 550 & 550 & 550 & 550 & 550 & 550 & 550 & 550 & 550 & 550 \\
\hline Lc (mm) & 210 & 190 & 200 & - & 210 & 210 & 210 & 210 & - & 200 & - & 220 & 220 & 220 & 200 & 200 \\
\hline $\operatorname{Lr}(\mathrm{mm})$ & 350 & - & 250 & - & 350 & 450 & 410 & 410 & 410 & 350 & 350 & 350 & 350 & 350 & - & 300 \\
\hline $\operatorname{Wr}(\mathrm{mm})$ & 40 & - & 36 & 300 & 40 & 40 & 40 & 40 & 40 & 40 & 40 & 40 & 40 & 40 & - & 36 \\
\hline$\alpha\left(^{\circ}\right)$ & 0 & - & 0 & 0 & 0 & 0 & 37 & 37 & 37 & 0 & 0 & 0 & 0 & 0 & - & 90 \\
\hline$h(\mathrm{~mm})$ & 13 & 13 & 13 & 13 & 12 & 12 & 12 & 12 & 12 & 12 & 12 & 12 & 12 & 12 & 12 & 13 \\
\hline Hum (mm) & 100 & 100 & 100 & 100 & 100 & 100 & 100 & 100 & 100 & 100 & 105 & 105 & 105 & 105 & 100 & 100 \\
\hline $\operatorname{HIm}(\mathrm{mm})$ & - & - & - & - & - & - & - & - & - & - & 90 & 90 & 90 & 90 & - & - \\
\hline $\mathrm{U}(\mathrm{mm} / \mathrm{s})$ & 0.33 & 0.33 & 0.33 & - & 0.5 & 0.33 & 0.33 & 0.5 & - & 0.33 & - & 0.075 & 0.16 & 0.06 & 0.33 & 0.33 \\
\hline$\underset{\left(\mathrm{kg} / \mathrm{m}^{3}\right)}{\rho}$ & 1416 & 1416 & 1416 & 1416 & 1426 & 1426 & 1426 & 1426 & 1426 & 1426 & 1434 & 1434 & 1434 & 1434 & 1426 & 1416 \\
\hline $\begin{array}{c}\Delta \rho o \\
\left(\mathrm{~kg} / \mathrm{m}^{3}\right)\end{array}$ & -80 & -80 & -18 & -80 & -77 & -26 & -77 & -77 & -77 & -77 & -19 & -19 & -19 & -19 & -77 & -18 \\
\hline$\underset{\left(\mathrm{kg} / \mathrm{m}^{3}\right)}{\Delta \rho c}$ & 102 & 102 & 102 & - & 99 & 99 & 99 & 99 & - & 99 & - & 74 & 74 & 74 & 99 & 102 \\
\hline $\begin{array}{c}\Delta \rho r \\
\left(\mathrm{~kg} / \mathrm{m}^{3}\right)\end{array}$ & 40 & - & 40 & - & 43 & 43 & 43 & 43 & 43 & 43 & 45 & 45 & 45 & 45 & - & 40 \\
\hline$\underset{\left(\mathrm{kg} / \mathrm{m}^{3}\right)}{\Delta \rho / m}$ & - & - & - & - & - & - & - & - & - & - & 6 & 6 & 6 & 6 & - & - \\
\hline$\eta \circ$ (kPa.s) & 353 & 353 & 356 & 353 & 597 & 505 & 597 & 597 & 597 & 597 & 670 & 670 & 670 & 670 & 597 & 356 \\
\hline$\eta c$ (kPa.s) & 157 & 157 & 157 & - & 320 & 320 & 320 & 320 & - & 320 & - & 420 & 420 & 420 & 320 & 157 \\
\hline$\eta r$ (kPa.s) & 180 & - & 180 & - & 440 & 440 & 440 & 440 & 440 & 440 & 340 & 340 & 340 & 340 & - & 180 \\
\hline ๆum (Pa.s) & 24 & 24 & 24 & 24 & 82 & 82 & 82 & 82 & 82 & 82 & 100 & 100 & 100 & 100 & 82 & 24 \\
\hline$\eta \operatorname{lm}$ (Pa.s) & - & - & - & - & - & - & - & - & - & - & 600 & 600 & 600 & 600 & - & - \\
\hline U* & 114 & 114 & 512 & - & 330 & 545 & 218 & 330 & - & 218 & - & 214 & 457 & 171 & 218 & 512 \\
\hline
\end{tabular}

Table 2: Experimental parameters: $W$ is the trench-parallel width of the subducting and overriding plates (see Figure 1c); Lo and Lc are the trench perpendicular lengths of the subducting and overriding plate, respectively; Lr and Wr are the length and width of the buoyant ridge, and $\alpha$ is the angle of the ridge axis with respect to the convergence direction; h, Hum and Hlm are thicknesses of silicone plates, the glucose syrup solution modeling the upper mantle, and the glucose syrup solution modeling the lower mantle, respectively; $U$ is the piston velocity; pum is the density of the upper mantle, and $\Delta \rho$ are buoyancies with respect to the upper mantle; $\eta$ are viscosities of silicone plates and glucose syrup solution, and $U^{*}$ is the dimensionless convergence velocity.

To model aseismic oceanic ridges in which the thicker crust increases the buoyancy of the lithosphere, we diminish the density of the silicone plate over its whole thickness as in Martinod et al. (2005). Such an approximation should not modify the general behavior of the subduction zone, assuming the oceanic crust is not delaminated from the mantle during the process of subduction. We also consider that the thickness of the lithosphere below ridges is similar to that of the neighboring oceanic plate. Buoyancy values and the scaling of density contrasts are detailed in Tables 1 and 2. In this experimental set, we study the effect on the process of subduction of buoyant ridges whose equivalent width in nature would be $\sim 250 \mathrm{~km}$. The buoyancy of the ridge in the reference experiment is that of a ridge whose sea-floor elevation would be 1900 meters above that of the neighboring oceanic plate (Table 1). This ridge would result from a 11 km-thicker oceanic crust (Cloos, 1993), corresponding to a sea-floor anomaly whose dimensions are approximately that of the Carnegie or Nazca ridges (see Martinod et al., 2005, for more discussions on the scaling of buoyant ridges).

We are forced by laboratory limitations to neglect thermal effects during the process of subduction. Temperature contrasts responsible for the negative buoyancy of subducting slabs are modeled by density contrasts, and keep constant throughout the experiments, assuming the slab in a quasiadiabatic condition. This assumption can be considered valid in the case the subduction velocity is large enough (larger than an equivalent of $1 \mathrm{~cm}^{-\mathrm{yr}^{-1}}$ ) to ensure that advection overcomes conduction (see Funiciello et al., 2003; Bellahsen et al., 2005). We also neglect phase changes, especially the 
transformation of the oceanic crust into eclogite, and the models we present here correspond to an endmember situation in which this metamorphic reaction would be sufficiently delayed to maintain the positive buoyancy of the subducting ridge. We also neglect the role of thermal convection in the subduction process, assuming that the upper mantle behaves as a passive Newtonian fluid and that the circulation within it is only caused by the mantle coupling with plate/slab system.
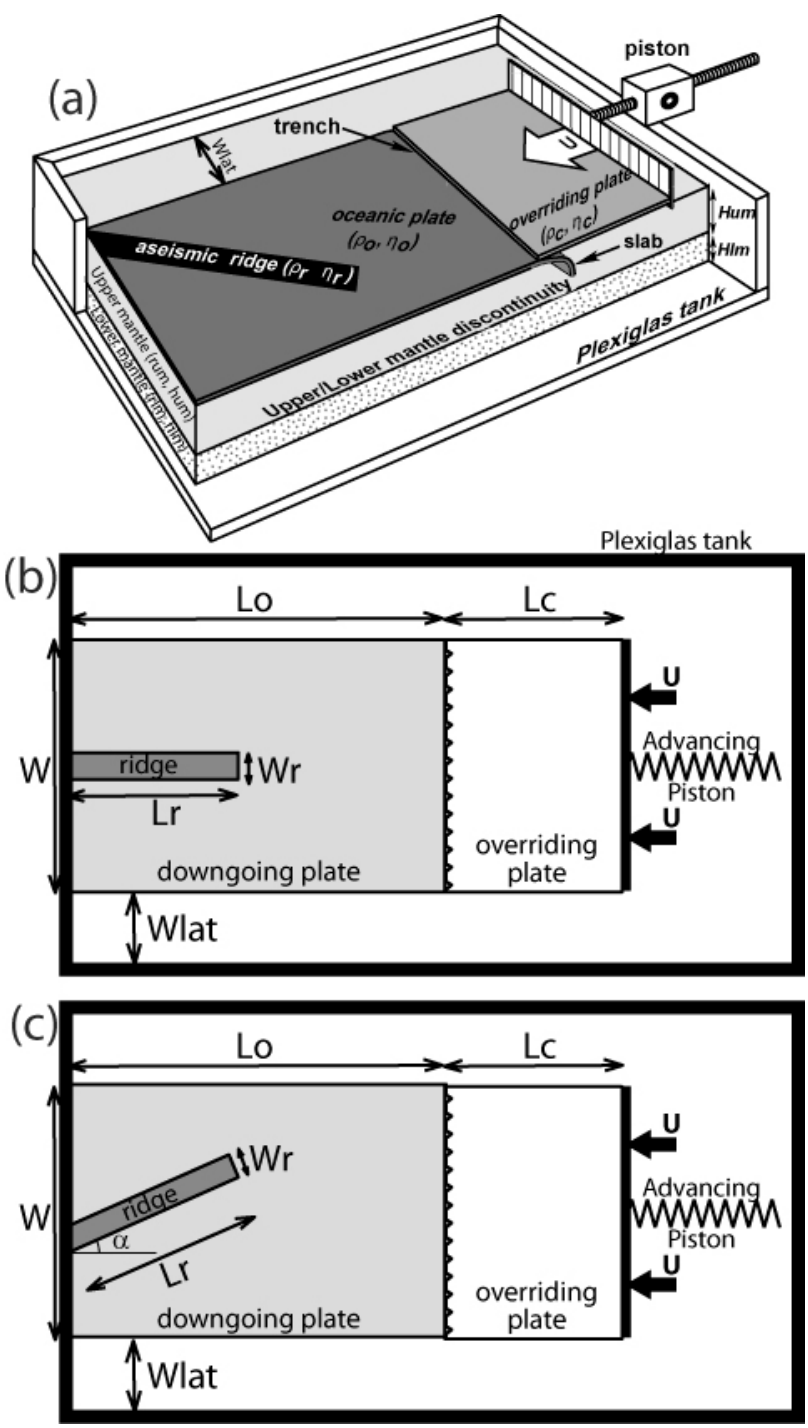

Figure 1: Experimental set-up. (a) $3 D$ view of analogue experiments. The piston pushes the overriding plate above the subduction zone at constant speed. (b) and (c) Top views of analogue models at the beginning of experiment, for trench-perpendicular ridges and oblique ridges, respectively. Dimensions are given in Table 2.

Scaling of experiments is detailed in Table 1 . Materials have been selected to respect the standard procedure for stress scaled down for length, buoyancy, viscosity, in a natural gravity field ( $g_{\text {model }}=$ $\left.g_{\text {Nature}}\right)$ as described by Weijermars and Schmeling (1986) and Davy and Cobbold (1991). From the simple scaling equations of Table 1 we find that $28 \mathrm{~s}$ and $1 \mathrm{~cm}$ in the experiment correspond to $1 \mathrm{Myr}$ and $66 \mathrm{~km}$ in nature, respectively. In the initial configuration, the leading edge of the silicone plate is forced downwards to a depth of $3 \mathrm{~cm}$ (corresponding to about $200 \mathrm{~km}$ in nature) inside glucose syrup as a means to initiate the subduction process.

Each experiment is monitored with a sequence of photographs taken at regular time in lateral and top views. We measure from them the motion of the trench, the surface deformation of plates and the dip of the slab, vs. time. In some experiments, we also measure the topography of the overriding plate using a laser beam. The accuracy of topographic measurements is $0.15 \mathrm{~mm}$. 


\section{Results}

We realized 15 models, among which 11 simulate the subduction of an oceanic plate with a buoyant ridge perpendicular or oblique with respect to the trench (see Table 2 for a complete description of the physical parameters of the experimental set). Four other models complete the experimental set: Experiments 2 and 15 reproduce Experiment 1 and 10, respectively, without any buoyant ridge within the subducting plate. Three models have also been done without any overriding plate, to study the effects of plate interaction on the process of subduction. In the following, we analyze (1) the 3-D geometry of the slab, (2) the deformation of the overriding plate and (3) the temporal evolution of the overriding plate topography.

\subsection{Slab geometry: Ridge subduction and slab flattening}

In all models, we observe a typical initial sequence. Following the beginning of experiment, a transitory regime corresponds to the period necessary for the slab to interact with the upper mantlelower mantle discontinuity, as fully described e.g. in Espurt et al. (2008). As soon as the bottom of the slab has deposited horizontally above this discontinuity, the regime of subduction reaches a steadystate (Figures 2 and 3). The dip of the slab and the trench-perpendicular strain rate within the overriding plate stabilize till the process of subduction becomes perturbed by the arrival of the buoyant anomaly at trench.

\subsubsection{Ridge subduction and slab flattening in the reference experiment}

Figure 2 shows top and lateral views of the reference experiment (experiment 1). We reported in Figure 3 the evolution of the dip of the slab measured $35 \mathrm{~mm}$ below the surface of the experiment. Experiment 2 corresponds to the reproduction of the reference experiment without any buoyant ridge. Comparison between them apart from the ridge influence indicates the experiment is reproducible (Figure 3).

The dip of the slab varies during the initiation of subduction. It first increases before the tip of the slab touches the upper mantle-lower mantle boundary. Then, it diminishes meanwhile the tip of the slab rotates to lie horizontally on the upper mantle-lower mantle boundary. It finally stabilizes with steady-state subduction (Figure 3).

The subduction of the buoyant ridge modifies the geometry of the subduction zone. In the reference experiment, the dip of the buoyant slab segment progressively decreases and finally stabilizes at a smaller value, while the dip of the slab far from the ridge basically maintains unchanged (Figures 2 and 3). We observe a $~ 130$ seconds delay between the arrival of the ridge at trench and the onset of slab dip decrease. This delay has also been observed by Espurt et al. (2008) in experiments modeling the subduction of a large oceanic plateau beneath an advancing overriding plate. In fact, when ridge subduction is beginning, most of the slab is composed of the previously subducted dense downgoing plate and the slab pull force is basically unchanged. Here, we only observe a modification of the slab dip after $\sim 45 \mathrm{~mm}$ (corresponding to $300 \mathrm{~km}$ in nature) of ridge subduction. 
(a) $25 \mathrm{~s}$

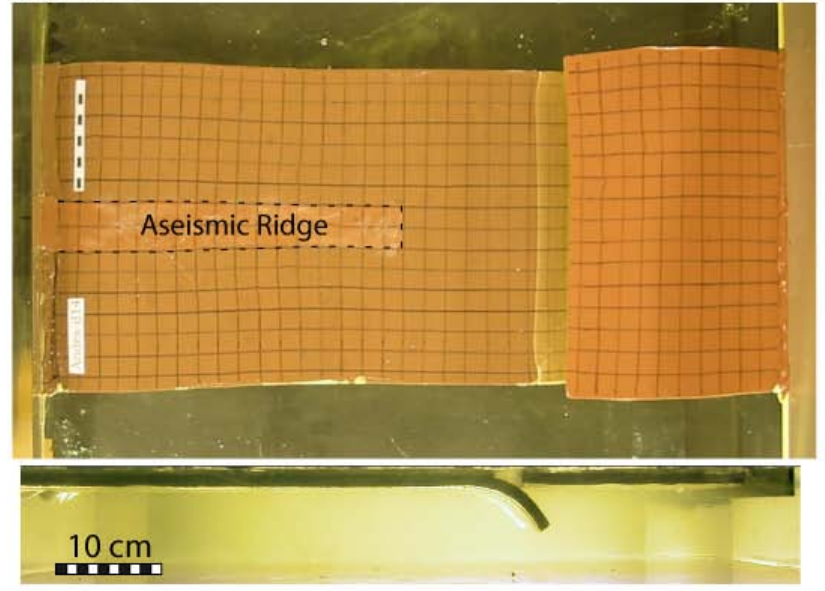

(c) $920 \mathrm{~s}$

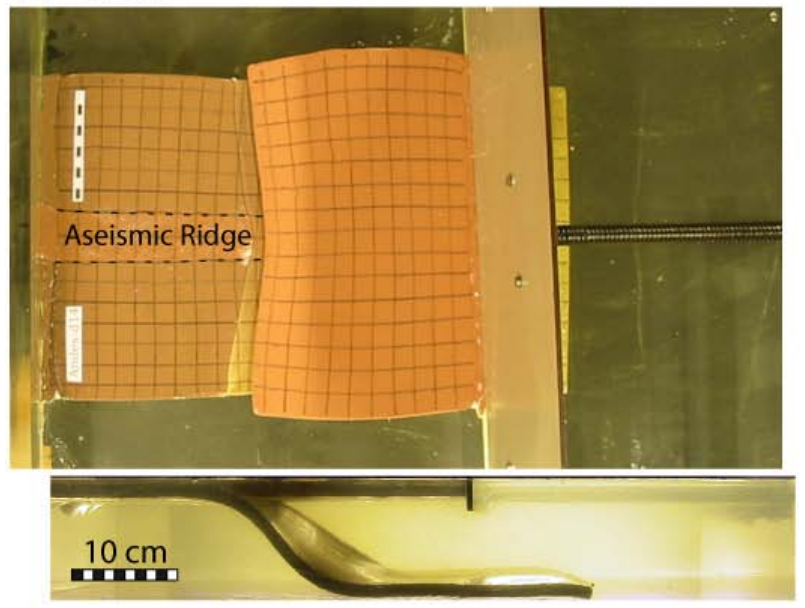

(b) $510 \mathrm{~s}$

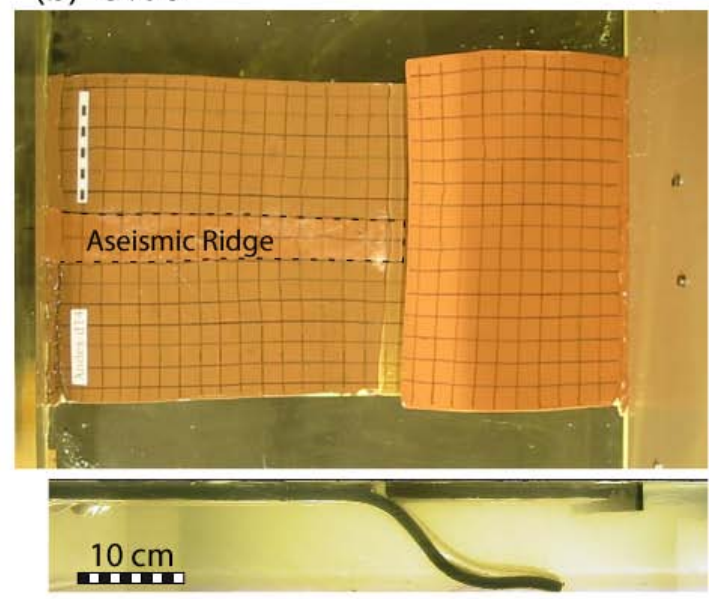

(d) $1340 \mathrm{~s}$

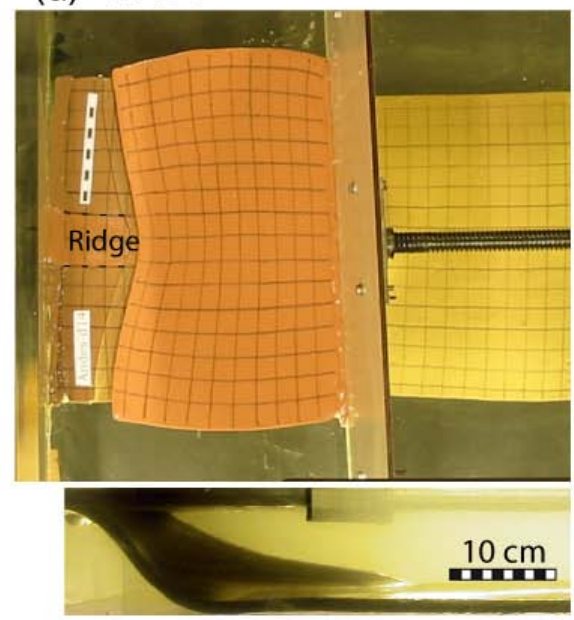

Figure 2: Top and lateral views of experiment 1. (a) 25 s of experiment: subduction is beginning, the tip of the slab does not touch the bottom of the Plexiglas tank yet. (b) $510 \mathrm{~s}$ of experiment: steady-state subduction of the dense silicone plate, the buoyant ridge is approaching the trench. (c) and (d) $920 \mathrm{~s}$ and 1340 s, respectively: the buoyant ridge is subducting; the dip of the slab segment corresponding to the buoyant ridge progressively decreases from $\sim 50^{\circ}$ to $\sim 25^{\circ}$, while it remains unchanged on lateral slab boundaries. Top views show the progressive indentation of the overriding plate by the subducting ridge, accommodated by opposite rotations on both sides of the ridge. 
Figure 3: (a) Dip of the slab vs. time in the reference experiment (experiment 1 , red color) and in experiment 2 (black color). The dip of the slab is measured $\sim 35 \mathrm{~mm}$ below the surface of the experiment, the corresponding depth being $\sim 250 \mathrm{~km}$ in nature. Empty arrows mark the moment the tip of the slab interacts with the bottom of the box. Stars mark the beginning of steady-state subduction. Filled red arrow at 520 seconds corresponds to the onset of ridge subduction in experiment 1 . Dotted red line: dip of the slab in the center of the plate (ridge subduction); solid red line: dip of the slab on lateral plate boundaries, $130 \mathrm{~mm}$ from the ridge. (b) Overriding plate trench-perpendicular shortening in experiments 1 and 2; Dotted line: deformation in the center of the plate, above the buoyant ridge; Solid line: deformation on lateral boundaries of the plate.
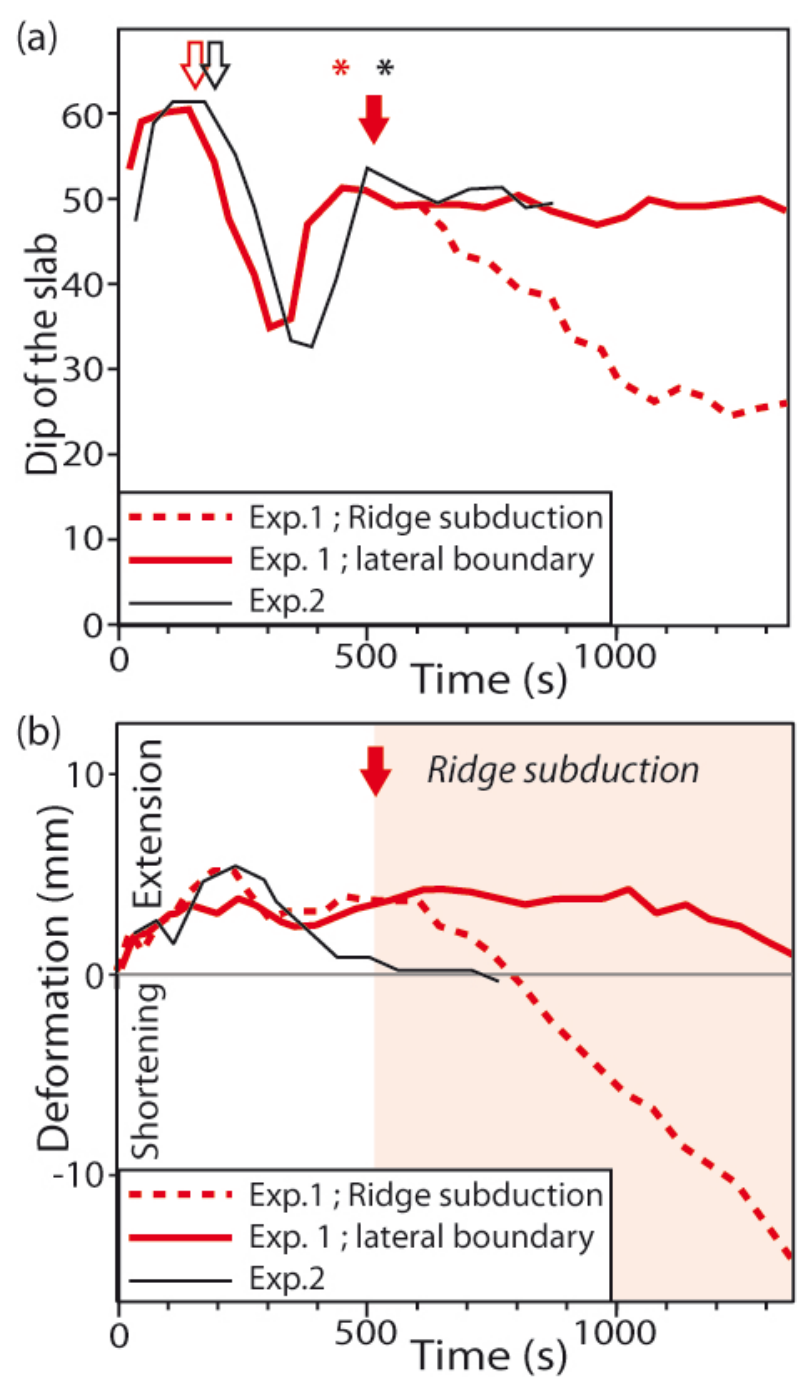

\subsubsection{Effects of convergence velocity on slab flattening following ridge subduction}

We realized eight experiments including a ridge perpendicular to the trench subducting beneath the overriding continent. The dip of the slab during the steady-state period of subduction of the dense plate, before ridge subduction, depends on the slab buoyancy and on the convergence velocity imposed by the piston: the faster the trench retreat, the shallower the dip of the slab. Espurt et al. (2008) observe that the advance of the overriding plate above the subduction zone does not change significantly the vertical component of the slab velocity in this kind of experiments, i.e., the slab dip directly depends on the trench retreat velocity. Following Espurt et al. (2008), we check that $\tan (\alpha)$ is proportional to $1 / U^{*}$, where $\alpha$ is the steady-state dip of the slab, and $U^{*}$ is the dimensionless convergence velocity defined as

$$
\mathrm{U}^{*}=\left(\eta_{\mathrm{o}} \cdot \mathrm{U}\right) /\left(\Delta \rho_{\mathrm{o}} \cdot \mathrm{g} \cdot \mathrm{h} \cdot \mathrm{H}_{\mathrm{um}}\right) \text {, }
$$

where $\eta_{\mathrm{o}}$ is the subducting plate viscosity, $U$ is the piston velocity, $\Delta \rho_{\mathrm{o}}$ is the negative buoyancy of the subducting plate, $h$ is the thickness of the subducting plate and $H_{u m}$ is the thickness of the viscous layer modeling the upper mantle (Figure 4). In figure 4, we also included results from experiments without any overriding plate: $U^{*}$ is then calculated using the same formula, in which $U$ is the steadystate subduction velocity. 


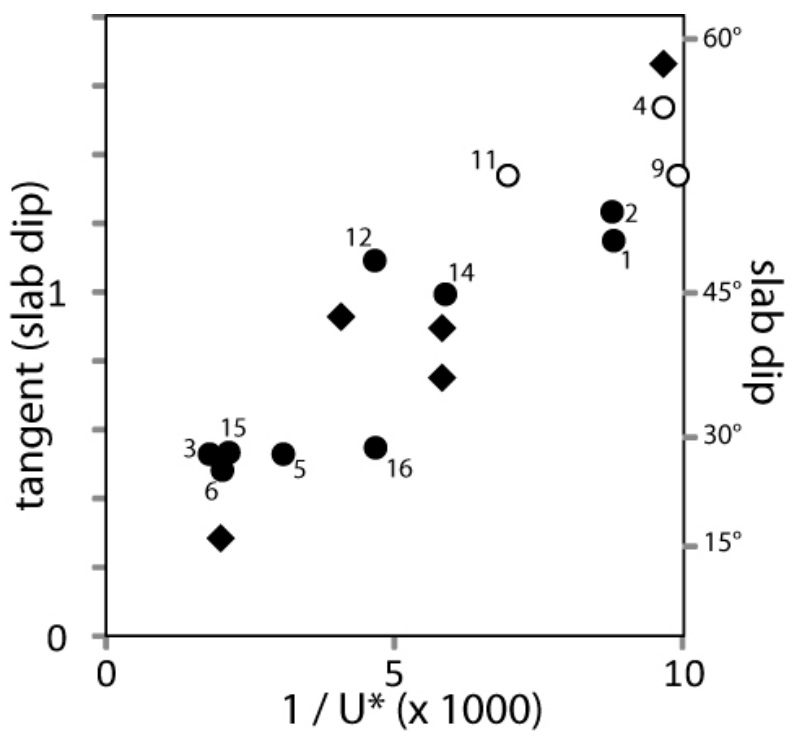

Figure 4: Steady-state dip of the slab during the subduction of a homogeneous plate vs. $1 / U^{*}$, where $U^{*}$ is the dimensionless convergence velocity. Results from the experimental set presented in this paper are marked using circles. Empty circles correspond to experiments without any overriding plate. We reported experiment numbers (Table 2). We also reported in this graph results from Espurt et al. (2008) (diamonds), all of the corresponding experiments including an overriding plate.

Figure 5: (a) and (b): dip of the slab and length of the horizontal slab segment vs. time in experiment 5 and 6 , respectively. The dip of the slab is measured $\sim 30 \mathrm{~mm}$ below the surface of the experiment, the corresponding depth being $\sim 200 \mathrm{~km}$ in nature. Solid line: dip of the lateral edges of the slab; dashed line: dip of the central part of the slab (ridge subduction); dotted line: trenchperpendicular length of the horizontal slab segment. Empty arrow: the slab touches the bottom of the box. Solid arrow: beginning of ridge subduction.
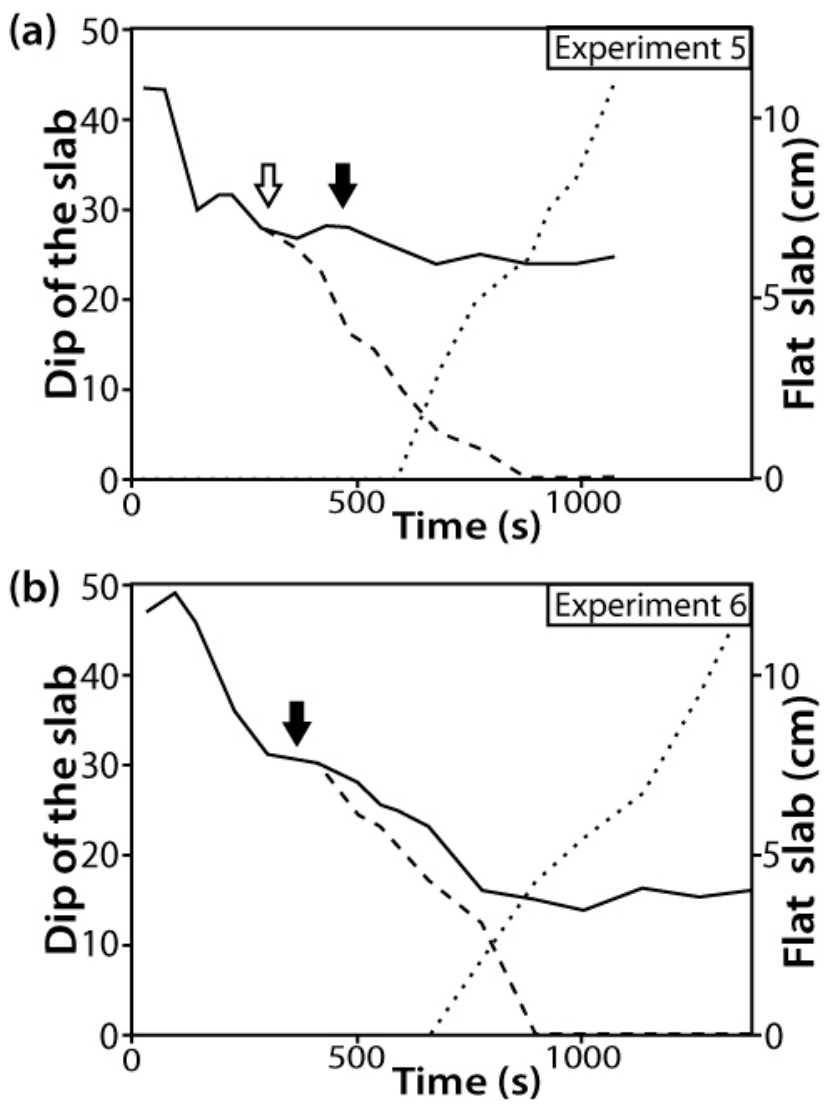

Experiment 5 is similar to the reference experiment, but with a $50 \%$ faster convergence velocity imposed by the motion of the piston and a larger viscosity of the subducting plate. The corresponding dimensionless convergence velocity $U^{*}$ is $\sim 3$ times larger than in the reference experiment. $U^{*}$ is even larger in experiment 6 . The steady-state dip of the slab before ridge subduction is thus smaller than in the reference experiment. Ridge subduction in these experiments further diminishes the dip of the slab, as it does in the reference experiment (Figure 5). Slab flattening occurs more rapidly and is more pronounced than in the reference experiment, and a horizontal slab segment finally appears beneath the overriding plate. The trench-parallel slab segment whose dip diminishes following the subduction of the buoyant ridge is also larger than in the reference experiment. In experiment 6 , although plates 
lateral boundaries are far from the ridge $(130 \mathrm{~mm}$ between the lateral boundary of the slab and the 40mm-wide ridge), their dip is largely affected by ridge subduction (Figure 5b).

\subsection{Ridge subduction and deformation of the overriding plate}

\subsubsection{Indentation of the overriding plate in the reference experiment}

Deformation in most of the experiments presented here is controlled by the convergence velocity imposed by the advance of a piston that pushes the overriding plate at constant speed. The upper plate stretches or shortens to accommodate differences between the imposed convergence velocity and, on the other hand, the intrinsic subduction velocity of the downgoing plate that results from the pull of the slab (i.e., the subduction velocity when the overriding plate motion is not imposed by lateral boundary conditions). Either increasing the piston velocity or decreasing the downgoing plate density favors the shortening of the overriding plate. The subducting plate being fixed in these experiments, the trench velocity is close to the velocity of subduction. A fraction of the velocity imposed by the piston is accommodated by the overriding plate deformation. The difference between the piston and trench velocities is the overriding plate deformation rate. However, this deformation being slow compared to the speed of the piston, the trench motion and the velocity of subduction are essentially constrained by the advance of the piston in this experimental set.

In all the experiments we did, the overriding plate shortening is larger above subducting ridges (see for instance Figure 2). The buoyancy of the ridge opposing its descent within the upper mantle, the upper plate needs to push it downwards to achieve subduction. The extra-shortening occurring above ridge subduction results in trench curvature, i.e. the ridge is indenting the overriding plate. Indentation is clearly visible in the reference experiment (see Figure 2). In this experiment, the ridge being perpendicular to the trench and thus parallel to the convergence velocity, it always subducts beneath the same portion of overriding plate. Then, the curvature of the trench increases with time till the end of experiment. Figure 3 shows that shortening above the ridge begins with a small delay ( 100 s) following the beginning of ridge subduction. This delay is comparable to that necessary to modify the dip of the slab. After 720 seconds of experiment, i.e. following $\sim 66 \mathrm{~mm}$ of ridge subduction, the shortening velocity above the subducting ridge stabilizes to $0.026 \mathrm{~mm} / \mathrm{s}$ while the slab pursues its flattening. Its dip decreases from $43^{\circ}$ at 720 seconds to $26^{\circ}$ at the end of experiment (Figure 2). Overriding plate shortening far from the ridge is minor $(0.005 \mathrm{~mm} / \mathrm{s})$ in this experiment. The Newtonian behavior of overriding plate results in smoothed and diffuse deformation patterns. Ridge subduction is accommodated by trench-perpendicular shortening above the ridge, and rotations on both sides of the ridge. Figure 6 shows the clockwise and counterclockwise rotations on both sides of the ridge in experiment 1 .

\subsubsection{Effects of the convergence velocity on the indentation of the overriding plate}

Indentation in ridge subduction experiments is not always as pronounced as in the reference experiment. Figure 6 shows three different trench-perpendicular ridge subduction experiments. Indentation significantly deformed the overriding plate in experiment 1 (Figure 6a), whereas it is hardly visible in experiment 3 (Figure 6c). 

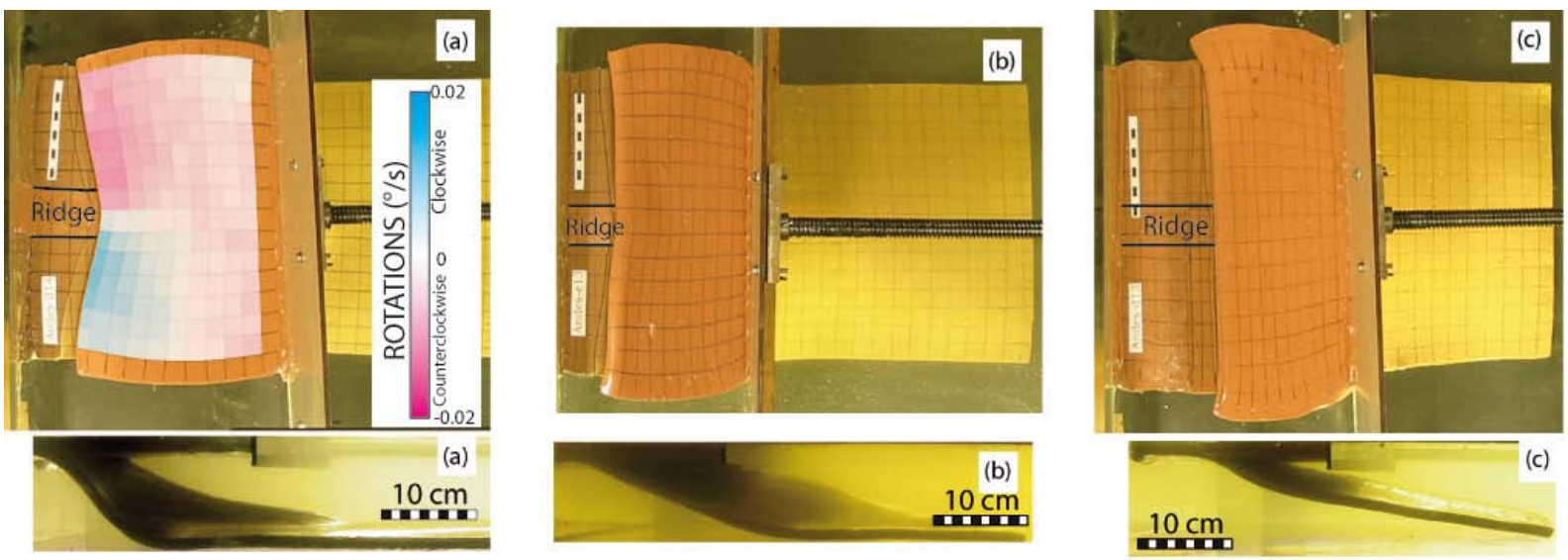

Figure 6: Comparison between 3 experiments modeling the indentation of the overriding plate by a subducting ridge: (a) Experiment 1, (b) experiment 10, (c) experiment 3. Above: top view of experiments; below: lateral views of experiments. The larger is the dip of the slab during the steadystate period of subduction of the dense downgoing plate, the more pronounced indentation is. In (a), we also report rotation rates in the overriding plate. Blue and pink colors mark clockwise and counter-clockwise rotations, respectively.

In experiment 3 , the dimensionless piston velocity $\mathrm{U}^{*}$ is much larger than in the reference experiment. The advance of the piston forces subduction at a much larger velocity than the intrinsic velocity of subduction of the plate, resulting in shallow dipping slab and in trench-perpendicular shortening within the entire overriding plate beginning before the onset of ridge subduction. In this experiment, the arrival of the buoyant ridge at trench does not modify the shortening velocity of the overriding plate, even in front of the locus of ridge subduction (Figure 7).

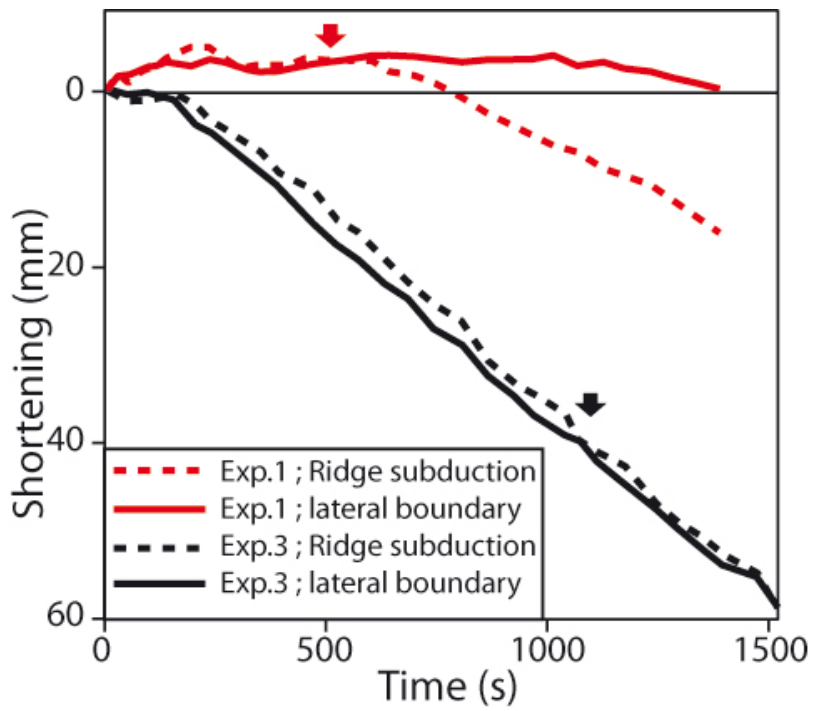

Figure 7: Comparison of overriding plate trench perpendicular shortening in experiment 3 (black curves) and 1 (red curves). Dashed lines mark the deformation in the center of the plate, above ridge subduction, while solid lines mark the shortening at lateral plate boundaries. Arrows mark the beginning of ridge subduction

Figure 8 shows the indentation velocity for the eight experiments in which the ridge is perpendicular to the trench. This velocity has been calculated as the difference between trench velocity above the ridge, and trench velocity on lateral plate boundaries, $130 \mathrm{~mm}$ from the ridge. In all these experiments, the indentation velocity is small compared to the total convergence velocity imposed by lateral boundary conditions. Indeed, indentation requires the deformation of the overriding plate, whose rigidity is close to that of the subducting plate in these experiments. For a comparison, in experiment 11 without any overriding plate, the indentation velocity is $\sim 31 \%$ of the subduction velocity, whereas it does not exceed $10 \%$ in experiments including an overriding plate. 


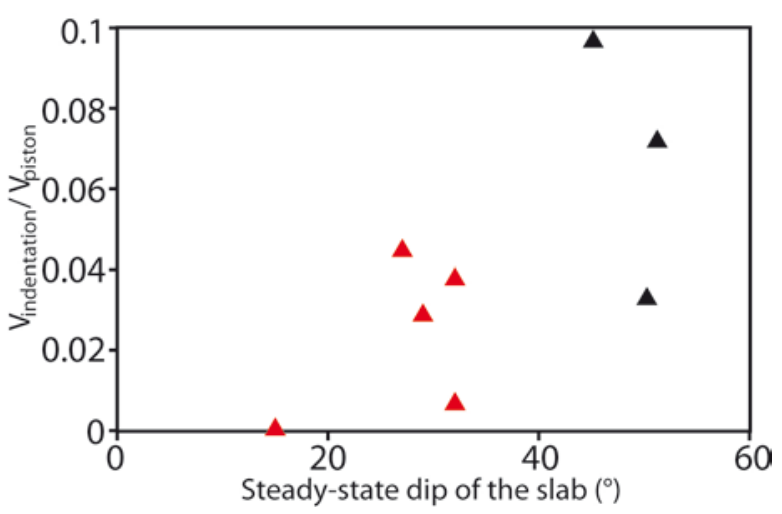

Figure 8: Normalized indentation velocity vs. the steady-state dip of the slab before ridge subduction. Red triangles correspond to experiments in which the overriding plate was shortening before ridge subduction. Black triangles mark experiments in which the overriding plate tectonic regime was neutral before ridge subduction. Indentation is smaller for small slab dips, i.e. when the overriding plate tectonic regime is compressional.

The velocity of indentation, however, does not only depend on the strength of overriding plate. Indeed, although the overriding plate strength is comparable in all the experimental set summarized in Figure 8, we observe very different indentation velocities as mentioned above. Figure 8 shows a correlation between the indentation velocity and the dip of the slab during the steady-state period of subduction that precedes the arrival of the buoyant ridge at trench. Indentation is smaller for shallow slab dips before ridge subduction. These experiments correspond to models in which the imposed convergence velocity is larger than the intrinsic velocity of subduction. They are also experiments for which the overriding plate shortens before ridge subduction, as for instance experiment 3 (Figure 7). Then, this experimental set suggests that indentation by a subducting ridge may depend on the initial dip of the slab and on the tectonic regime of the overriding plate. Indentation by the ridge is more pronounced when the tectonic regime of the overriding plate is extensional or neutral than when it is compressional.

\subsubsection{Indentation during the subduction of an oblique ridge}

Experiments 7, 8 and 9 model the subduction of oblique ridges. Experiment 9 has been done without any overriding plate. This experiment simulates a subduction in which the overriding plate would not interfere with the subduction process and would not exert any control on the motion of the trench. The ridge being oblique with respect to the convergence velocity, the locus of ridge subduction at trench progressively migrates laterally (Figure 9).

We report in Figure 9 the subduction velocity along 5 cross sections perpendicular to the initial geometry of the trench. Subduction slows down when the ridge is subducting, resulting in arched trench geometry whose curvature migrates laterally following the locus of ridge subduction. Figure 9 shows that the subduction velocity slows down before the ridge subducts along profiles, because it is affected by ridge subduction that already initiated laterally. Slow subduction lasts more than $500 \mathrm{~s}$ following ridge subduction, because although the ridge has migrated laterally, it still diminishes the slab buoyancy at depth.

In oblique ridge experiments including an overriding plate (Figure 10), ridge subduction results in the shortening of the overriding plate as in trench-perpendicular ridge experiments presented in previous sections. The overriding plate reduces trench curvature. We observe again clockwise and counterclockwise rigid body rotations within the overriding plate on both sides of the ridge. The central part of the overriding plate first rotates counter-clockwise (Figure 10a). Afterwards, following the migration of ridge subduction beneath the other half of the plate, clockwise rotations occur in the central part of the plate and the final orientation of the trench is approximately parallel to its initial configuration (Figure 10d). 

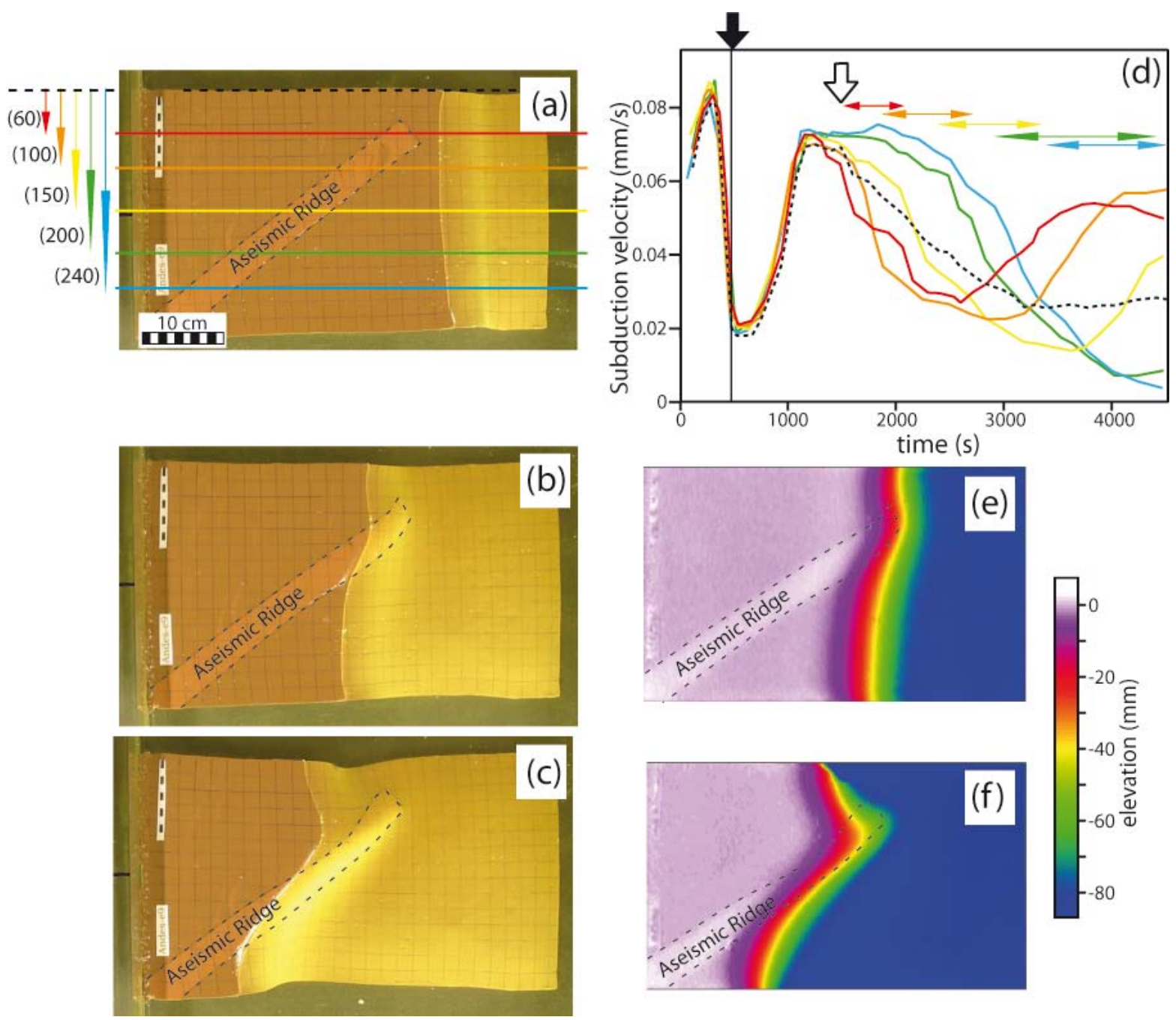

Figure 9: "Free" subduction of an oblique buoyant ridge: Top-views of experiment 9 following (a) 1350 s, (b) $2280 \mathrm{~s}$ and (c) $3240 \mathrm{~s}$ of experiment. (d) subduction velocity along 5 trench-perpendicular profiles. These profiles are located 60, 100, 150, 200 and $240 \mathrm{~mm}$ from the lateral boundary of the plate, as indicated in (a). The dotted black line shows the average subduction velocity. The solid black arrow marks the interaction between the slab and the bottom of the box, and the empty arrow corresponds to the initiation of ridge subduction. Colored arrows mark the period of ridge subduction at trench for each considered profile. (e) and (f), topography of the subducting plate following $2290 \mathrm{~s}$ and $3215 \mathrm{~s}$ of experiment, respectively.
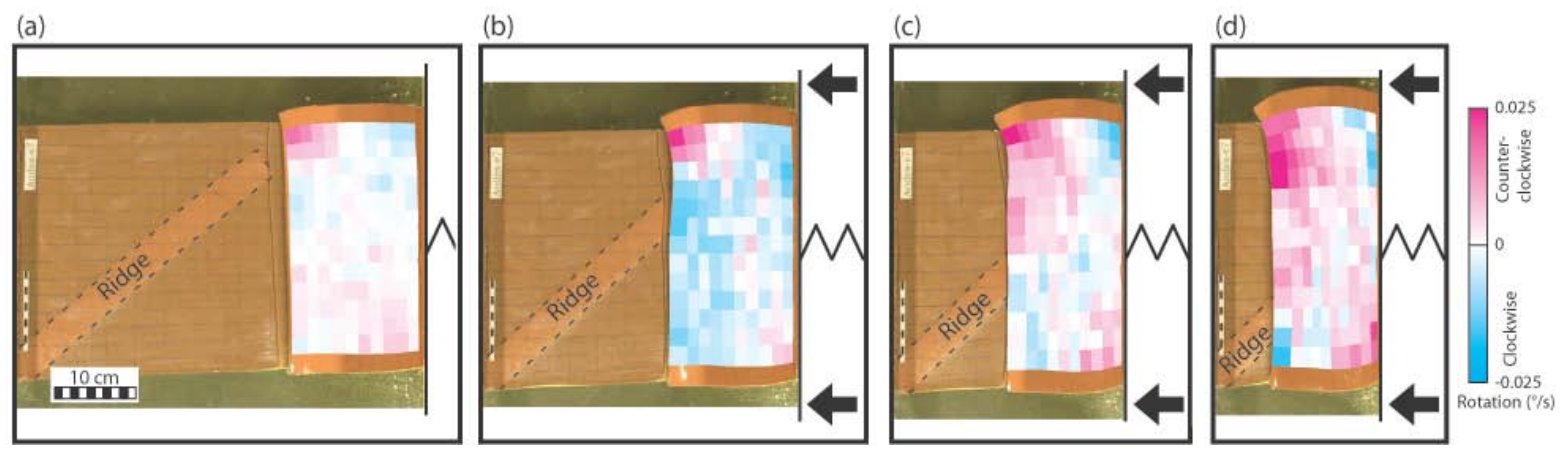

Figure 10: Experiment 8 modeling the subduction of a ridge oblique with respect to the trench beneath an advancing plate. Top views following (a) $670 \mathrm{~s}$, (b) $858 \mathrm{~s}$, (c) $1040 \mathrm{~s}$ and (d) $1230 \mathrm{~s}$ of experiment. We report rigid body rotation rates in the overriding plate (a) before $670 \mathrm{~s}$, (b) between 670 and $858 \mathrm{~s}$, (c) 858 and $1040 \mathrm{~s}$, (d) 1040 and 
1230 s of experiment. Blue and pink colors mark clockwise and counter-clockwise rigid body rotations, respectively. Note that the area affected by counter-clockwise rotations widens following the lateral migration of ridge subduction.

\subsection{Topography}
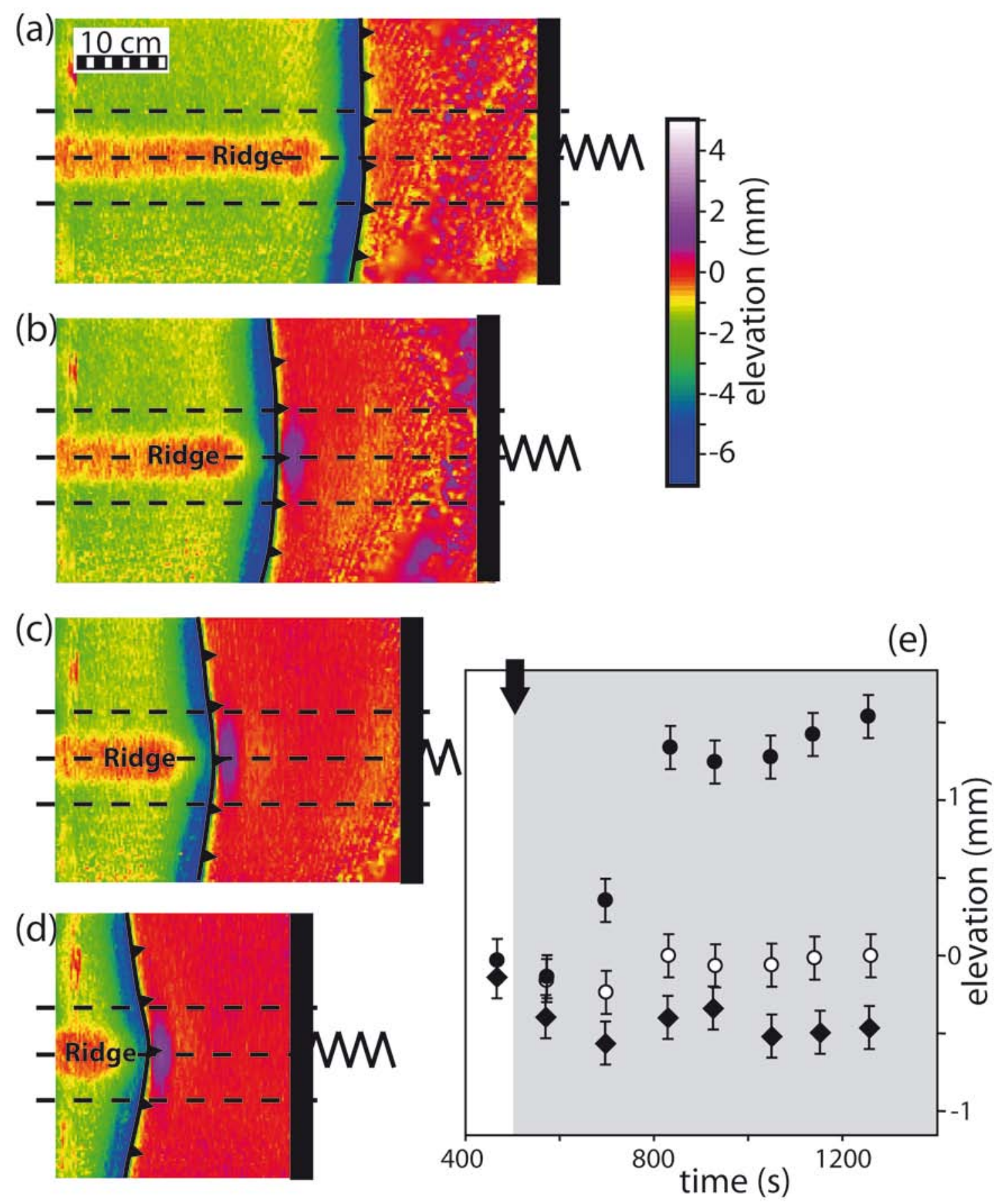

Figure 11: Topography of experiment 1 following (a) 572 s, (b) 834 s, (c) 1050 s and (d) 1254 s of subduction. The zero elevation corresponds to the average topography of the overriding plate before ridge subduction. (e) Circles report the evolution of the highest elevation of the active margin orogen; black circles: above the subducting ridge; white circles: on both sides of the ridge, $50 \mathrm{~mm}$ from the centre of the ridge. Diamonds mark the lowest elevation of the "back-arc" depression localized behind the active margin orogen, above the subducting ridge. The solid black arrow corresponds to the initiation of ridge subduction. 
We recorded the topography of experiments using a 3D laser scanner. We preliminary checked that the difference in elevation of both the ridge and the overriding continental plate with respect to the ocean at rest (i.e. before subduction initiation) obeys isostasy. The surface of the overriding plate is between 1 and $1.5 \mathrm{~mm}$ higher than that of the downgoing plate, depending on the experimental parameters.

In experiment 1 , the overriding plate does not shorten except above the subducting ridge (Figure 3). We do not observe any noticeable change in the topography of the overriding plate before the beginning of ridge subduction. In contrast, the overriding plate rapidly uplifts above the ridge following the beginning of ridge subduction and reaches a maximum elevation of $\sim 1.4 \mathrm{~mm}$ above the average topography of the plate at $\sim 830$ seconds of experiment (following $\sim 105 \mathrm{~mm}$ of ridge subduction, see Figure 11). Afterwards, the maximum elevation of the overriding plate does not increase anymore despite the overriding plate shortens in front of the ridge till the end of experiment. A gentle depression forms behind the uplifted area. Its maximum depth stabilizes to $0.4 \mathrm{~mm}$ following 1000 seconds of experiment, i.e. $\sim 160 \mathrm{~mm}$ of ridge subduction (Figure 11).

Despite the imposed convergence velocity is larger in experiment 5, the evolution of topography in this experiment shares some common characteristics with experiment 1 . Larger convergence velocity results in a flatter subduction zone and in shortening of the overriding plate beginning before the onset of ridge subduction. The shortening of the overriding plate increases following 320 seconds of experiment, when the tip of the slab touches the bottom of the Plexiglas tank. It results in the appearance of a relief rapidly growing above the subduction zone, despite the buoyant ridge has not subducted yet (Figure 12). This observation shows that the uplift of the overriding plate does not only result from ridge subduction in this experiment. However, following ridge subduction, the maximum elevation of the overriding plate stabilizes to values close to $4.8 \mathrm{~mm}$ above the ridge and $3.8 \mathrm{~mm}$ laterally, showing the effect of the ridge. Again, the maximum elevation is reached following $\sim 105 \mathrm{~mm}$ of ridge subduction, corresponding to $\sim 700 \mathrm{~km}$ in nature. Afterwards, the shortening of the overriding plate results in the widening of the chain, but its maximum elevation does not increase anymore. The maximum differential elevation of the chain above the ridge compared to its lateral segments is $\sim 1.3$ $\mathrm{mm}$, and this value stabilizes to $0.9 \mathrm{~mm}$ at the end of experiment. This difference in elevation is exactly that between the ridge and the surface of the downgoing plate in this experiment.

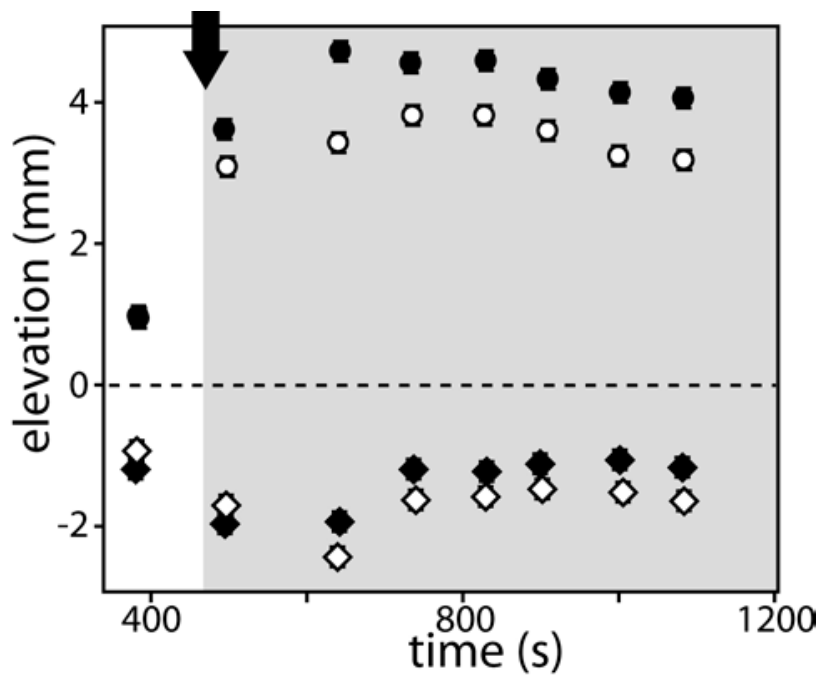

Figure 12: same as Figure 11e for experiment 5: Circles report the evolution of the elevation of the active margin orogen; black circles: above the subducting ridge; white circles: on both sides of the ridge, 50 $\mathrm{mm}$ from the centre of the ridge. Diamonds mark the elevation of the "back-arc" depression localized behind the active margin orogen; black diamonds: above the subducting ridge; white diamonds: on both sides of the ridge. The filled arrow marks the beginning of ridge subduction. 

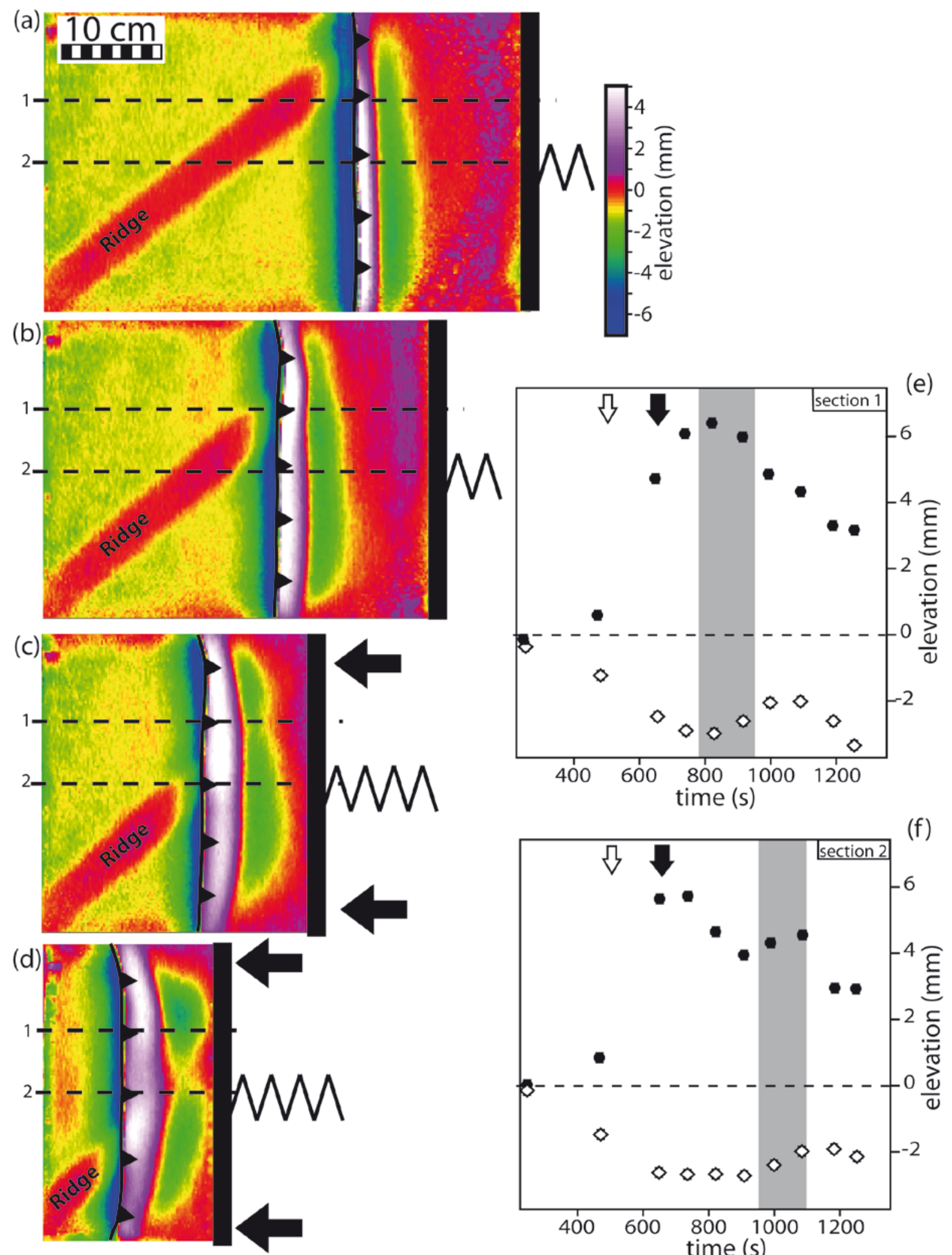

(f)

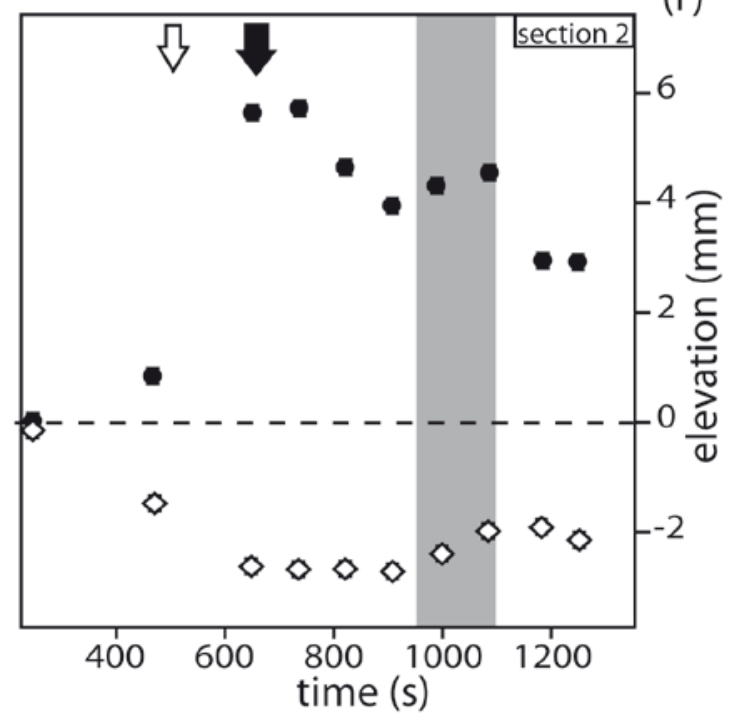

Figure 13: Topography of experiment 8 following (a) $650 \mathrm{~s}$, (b) $820 \mathrm{~s}$, (c) $990 \mathrm{~s}$ and (d) $1190 \mathrm{~s}$ of subduction. (e) and ( $f$ ) Black dots and white diamonds mark the elevation of the active margin orogen and that of the "back-arc" depression localized behind the active margin orogen, respectively, along two trench-perpendicular profiles whose position is indicated in (a). Grey stripes show the period of ridge subduction at trench for the two considered cross-sections. The filled arrow marks the beginning of ridge subduction, and the empty arrow the moment the slab touches the bottom of the Plexiglas tank. 
The "back-arc" depression localized behind the active margin orogen is also uplifted by the subduction of the ridge. Indeed, at the end of experiment, the depression is only $1.1 \mathrm{~mm}$ deep above the ridge vs. $1.7 \mathrm{~mm}$ elsewhere. At the beginning of ridge subduction, in contrast, the depression was deeper above the ridge, and reached a maximum depth of $2.0 \mathrm{~mm}$. In experiment 1, we also observed a deeper depression above the ridge behind the active margin orogen, but this depression maintained deeper till the end of experiment. This different behavior results from the appearance of the horizontal slab segment in experiment 5 , the buoyant subducting plate uplifting the overriding continental plate far from the trench. This experiment shows that the slab buoyancy may support topography at great distances from the trench in case the slab has a shallow inclination within the upper mantle.

Experiments reproducing the subduction of an oblique ridge beneath an advancing continent show similar topographic evolution. In experiment 8 , a positive relief appears close to the trench as soon as the subducting plate interacts with the bottom of the Plexiglas tank. The relief reaches a maximum elevation shortly after the beginning of ridge subduction (Figure 13). Afterwards, the maximum elevation of the overriding plate decreases while the width of the chain increases (Figure 13). The ridge being oblique with respect to the direction of convergence, the locus of ridge subduction progressively migrates laterally during the experiment. If we consider trench-perpendicular profiles as in Figure 13e and 13f, the ridge subducts at trench, then subducts beneath the "active margin orogen" (the proximal part of the overriding plate), and finally subducts beneath the "back-arc" area. We observe this effect in the topography of the overriding plate. The chain being closer from the ridge, its elevation increases as soon as the ridge subducts at trench and decreases rapidly following ridge subduction. In contrast, the "back-arc" depression uplifts approximately 150 seconds following ridge subduction, because it uplifts when the ridge is located beneath it.

\section{Discussion:}

\subsection{Physical behavior of analogue models}

\subsubsection{Slab dip}

This experimental set confirms that the dip of the slab prior to ridge subduction depends on the slab buoyancy and on the convergence velocity imposed by the piston. O'Driscoll et al. (2012) show that thick overriding plate increases slab suction which, in turn, may explain why the dip of the slab beneath continents is $\sim 20^{\circ}$ shallower than beneath oceanic upper plates (Lallemand et al., 2005). In this experimental set, we do not see any clear dependence of the slab dip on the presence of an overriding plate. Another series of experiments should be specifically dedicated to address this question.

In this experimental set, ridge subduction systematically results in the diminution of the dip of the slab. Some experiments in which lateral boundary conditions impose a rapid trenchward motion of the overriding plate even result in the appearance of a flat slab segment centered on the position of the ridge. Ridge subduction leading to smaller slab dip may seem an obvious result, since a lighter slab sinks more slowly within the upper mantle. Nevertheless, slab dip diminution is also a consequence of the adopted boundary conditions that impose a constant convergence velocity. The overriding plate deformation being slow compared to the imposed convergence velocity, lateral boundary conditions largely control the velocity of subduction. In contrast, Martinod et al. (2005) present analogue experiments in which the subduction of the downgoing plate is not influenced by the overriding plate ("free subduction experiments"). In these experiments, the subduction of buoyant ridges results in a diminution of the slab-pull force, in a decrease of the subduction velocity and, in turn, in an increase of the dip of the slab beneath the subducting ridge. Thus, the consequences of ridge subduction on the dip 
of the slab largely depend on boundary conditions. In nature, if we consider that the slab-pull force is the main engine of subduction that drives plate kinematics, the subduction of a buoyant ridge may affect the trenchward subducting plate velocity. However, if the subducting plate is large, ridge subduction should only marginally modify the pull of the slab and the convergence velocity.

In any case, experiments confirm that ridge subduction only progressively affects the dip of the slab. At the beginning of ridge subduction, indeed, the ridge is pulled downwards by the dense slab. The average slab buoyancy only diminishes when a significant amount of ridge enters the slab. It may explain why the relationship between ridge subduction and the dip of the slab is not straightforward.

\subsubsection{Deformation and uplift of the overriding plate}

Ridge subduction in experiments increases horizontal trench-perpendicular compression within the overriding plate. In this experimental set, the thickness of both the overriding and subducting plates are equal, and the viscosity of the overriding plate is approximately half that of the subducting plate. Hence, although compression favors shortening above ridge subduction, the overriding plate rate of shortening remains small compared to the velocity of subduction, and indentation is modest in these experiments compared to the marked arched geometry of the trench in free subduction experiments (experiment 11). Indentation is accompanied by clockwise and counterclockwise rotations on both sides of the ridge. Silicone plates behave as quasi-Newtonian fluids for the applied experimental strain-rates (e.g., Weijermars and Schmeling, 1986). Thus, deformation in silicone plates is diffuse, and, we do not observe any of the faults that may also accommodate indentation in nature.

Ridge subduction also modifies the overriding plate topography. When the dip of the slab is large, the subducting ridge uplifts the overriding plate close to the trench. In experiment 1 , the maximum uplift above the ridge is $1.5 \mathrm{~mm}$, which is larger than the difference in elevation between the ridge and the downgoing plate $(1.1 \mathrm{~mm})$. The maximum elevation of the overriding plate is reached following $\sim 105 \mathrm{~mm}$ (corresponding to $\sim 700 \mathrm{~km}$ in nature) of ridge subduction (Figure 11). Afterwards, the elevation of the higher part of the overriding plate does not increase anymore, despite the overriding plate shortens in front of the ridge till the end of experiment (Figure 3). Within the overriding plate, a gentle depression appears behind the uplifted area. At the beginning of ridge subduction, this depression is localized $60 \mathrm{~mm}$ from the trench. In experiment 1 , it progressively migrates towards the trench and stabilizes $\sim 40 \mathrm{~mm}$ from the trench.

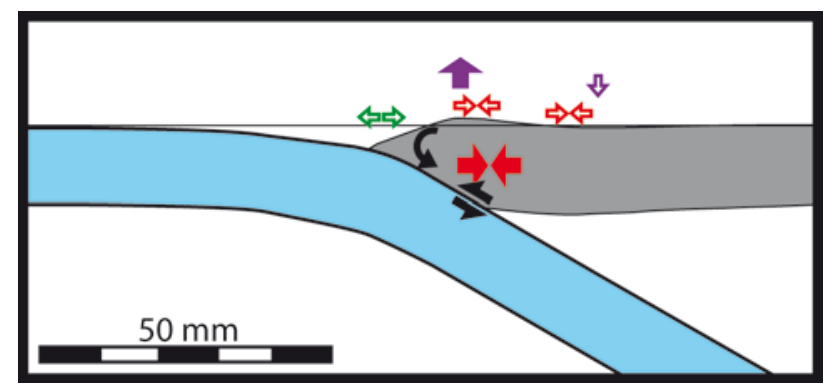

Figure 14: Interpretative cross section of the central part of experiment 1, above the ridge, following 1140 seconds. The overriding plate is in grey and the subducting ridge in light blue. Surface topography is that measured using the laser, the dip of the slab within the upper mantle is that observed in lateral photographs, and the thickness of the overriding plate is deduced from surface deformation. Empty green and red arrows mark trenchperpendicular surface extension and shortening, respectively. Solid red arrows mark plate thickening. Ridge subduction results in uplift close to the interplate contact, and in the appearance of a flexural depression within the overriding plate interiors. Surface extension close to the trench results from interplate friction. 
Figure 14 shows a semi-interpretative cross-section of the central part of experiment 1 above the ridge, following 1140 seconds, i.e. close to the end of experiment. At that time, an equivalent of 1400 $\mathrm{km}$-long ridge has been subducted. In this figure, the topography corresponds to that registered using the laser, the dip of the slab within the upper mantle is that observed using lateral photographs, and the thickness of the overriding plate is deduced from surface deformation. The overriding plate thickening is everywhere smaller than $15 \%$. The isostatic component of uplift resulting from this thickening is $\sim 0.15 \mathrm{~mm}$, showing that the overriding plate shortening does not exert a major control in the topography of this experiment.

Topography above subduction zones also responds to stresses induced by the descent of the slab within the upper mantle. This dynamic response results in the deflection of the overriding plate above the subduction zone. For comparable experiments characterized by the subduction of the sole downgoing lithosphere, Husson et al. (2012) estimate the dynamic deflection between $0.075 \mathrm{~mm}$ and $0.25 \mathrm{~mm}$. Ridge subduction increases the average slab buoyancy, diminishes its downward component of velocity and, in turn, diminishes the downward deflection of the overriding plate. Hence, ridge subduction should result in a long-wavelength uplift of the overriding plate, but the magnitude of this uplift is probably too small to be evidenced in this experimental set.

In fact, we observe that the maximum uplift is located above the interplate contact, confirming it is essentially supported by the flexure of the subducting plate. The depression behind the uplifted area is the flexural response of the overriding plate to the uplift induced by ridge subduction. The viscous behavior of the overriding plate explains why the depression approaches the uplifted area as soon as uplift above the interplate contact stops (e.g., Watts, 2001).

In experiment 1 , overriding plate shortening above ridge subduction is essentially accommodated between the uplifted area and the flexural depression (Figure 14). Some trench-perpendicular extension is observed at the surface of the overriding plate close to the trench. This extension shows that the base of the overriding plate is driven downwards by subduction along the interplate contact. This deformation mimics the effects of tectonic erosion that may explain for example why the trenchperpendicular strain regime within the Andean fore-arc is extensive, which contrasts with the shortening concentrating on the eastern side of the Andes (e.g., Adam and Reuther, 2000). Ridge subduction is also accompanied in these experiments by trench-parallel extension of the overriding plate. This extension is favored by the adopted lateral boundary conditions and by the gravity spreading of the buoyant plate above the low-viscosity solution.

\subsubsection{Convergence velocity, appearance of flat-slab segments, and overriding plate deformation}

Figure 8 shows that the indentation of the overriding plate by a trench-perpendicular ridge is generally more pronounced for small convergence velocities in our experiments. This phenomenon reflects the evolution of the slab geometry during ridge subduction. In these experiments, we only observe the evolution of the slab geometry using lateral views of experiments. Thus, we do not know precisely the 3D-geometry of the slab and the trench-parallel width of the flat slab segment. Nevertheless, we note that the dip of the lateral boundaries of the slab is poorly affected by ridge subduction when the convergence velocity is small (e.g., experiment 1, Figure 3) and, in contrast, that ridge subduction diminishes the dip of the slab everywhere in the experiment for larger convergence velocities. The larger is the subduction velocity, the higher is the slab strength, the smaller is its deformation and its trench-parallel curvature, and the wider is the horizontal slab segment. Then, indentation is smaller for higher convergence velocities, i.e. when the overriding plate is shortening. 
Larger convergence velocities also result in flatter slabs, and ridge subduction possibly results in the appearance of a horizontal slab segment. In these experiments, the positive relief also rapidly reaches a maximum elevation following the beginning of ridge subduction (Figure 12). Figure 15 shows the evolution of topography in experiment 5 along a cross-section located close to the lateral boundary of the ridge. Both the uplift of the overriding plate close to the trench and the thickening of the plate are much larger than in experiment 1 . Here again, the isostatic component of uplift resulting from the thickening of the overriding plate only accounts for a minor part of uplift ( $\sim 0.8 \mathrm{~mm}$ vs. $4 \mathrm{~mm}$ of total uplift). At the beginning of ridge subduction, the uplift is rapid and accompanied by a deep depression whose position stabilizes rapidly $\sim 40 \mathrm{~mm}$ from the trench, just behind the end of the interplate contact area (Figure 15b). Afterwards, slab flattening is marked in the topography (1) by a widening of the chain towards the hinterland, and (2) by the uplift of the basin that had initially appeared behind the chain, showing that the flat slab supports the uplift of both the chain and the back-arc depression.

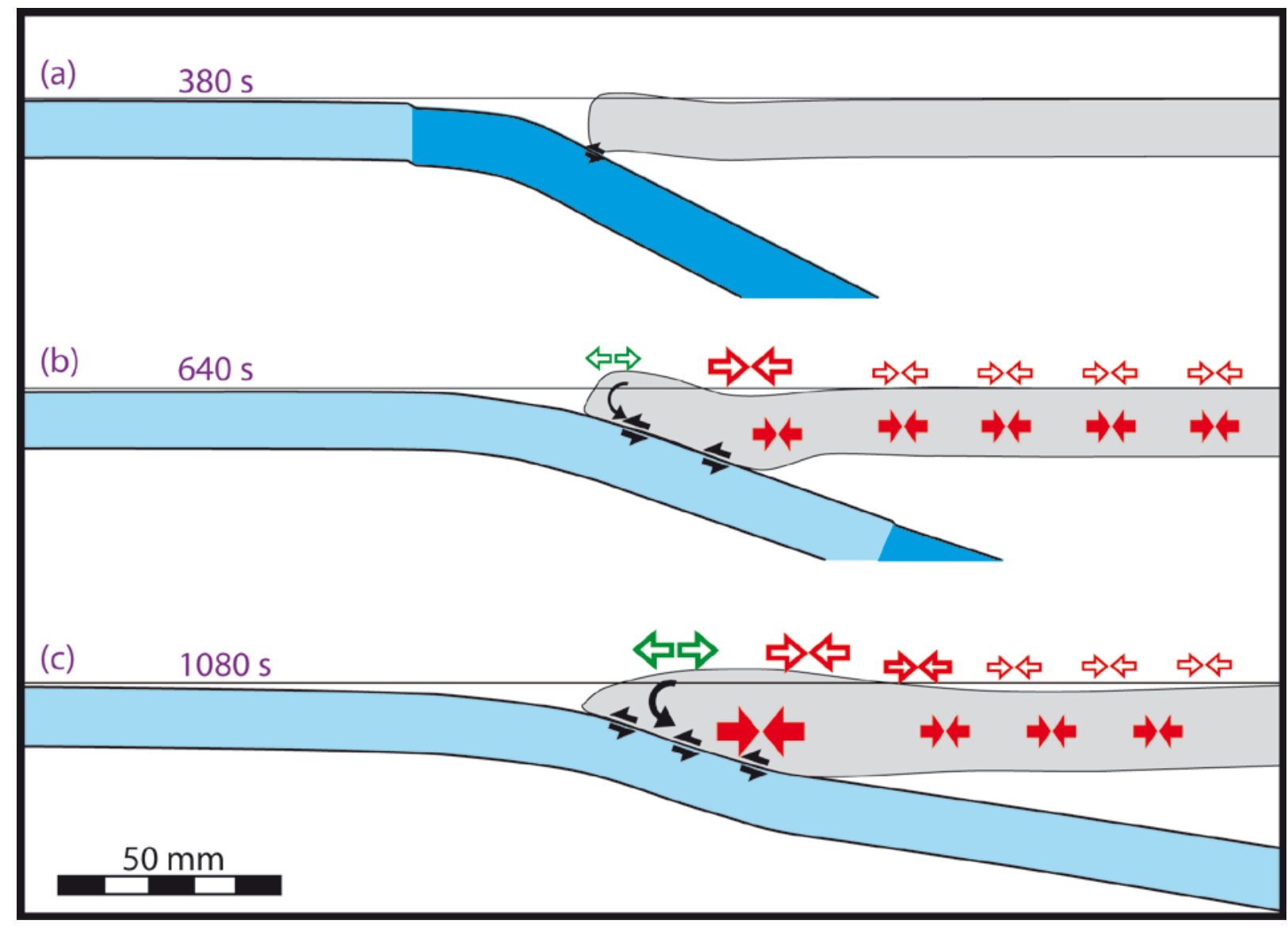

Figure 15: Same as Figure 14, for experiment 5. The overriding plate is in grey, the dense subducting plate in dark blue and the ridge in light blue. (a) $380 \mathrm{~s}$ of experiment, before ridge subduction; (b) $640 \mathrm{~s}$ of experiment, beginning of ridge subduction; (c) $1080 \mathrm{~s}$ of experiment, horizontal subduction.

In case the ridge is oblique with respect to the convergence velocity, its locus of subduction migrates laterally, and the rotation pattern within the overriding plate follows this migration. Thus, a given point within the overriding plate should successfully register rotations in opposite directions before and after the ridge has subducted beneath it. The timing of uplift and subsidence resulting from the migration of the ridge beneath the overriding plate is delayed within the back-arc basin compared to that in the active margin orogen located closer from the trench. Figure 13 shows the rapid subsidence of the overriding 
plate following the lateral migration of the ridge. This subsidence results from the collapse of the flat slab segment within the upper mantle following the lateral migration of the ridge (Figure 9).

\subsection{Comparison with natural examples}

Experiments presented above show that ridge subduction may (1) modify the dip of the slab, (2) result in the indentation of the overriding plate and (3) uplift the overriding plate. In the following, we illustrate these three aspects of ridge subduction in natural examples.

\subsubsection{Ridge subduction and slab dip}

Experiments show that the subduction of buoyant ridges may diminish the dip of the slab in case the convergence velocity is controlled by lateral boundary conditions. In nature, smaller slab dips coinciding with the subduction of oceanic ridges are generally observed in the Eastern Pacific subduction zones (e.g., Rosenbaum and Mo, 2011, for review), where the subducting plate is young and the average slab dip is small. Ridge subduction may even result in some cases in the appearance of a horizontal slab segment. For instance, it has been proposed that the Peruvian flat slab segment results from the subduction of both the Nazca Ridge and another oceanic plateau (the Inca Plateau) that subducted beneath Northern Peru 10-12 Myrs ago (Gutscher et al., 1999). Beneath Chile, Yañez et al. (2001) show that the location of the subducted portion of the Juan Fernandez chain precisely coincides with the southern edge of the flat slab segment, and with a cluster of deep earthquakes indicating a causal relationship between the ridge and horizontal subduction (Figure 16). Subducting ridges may also have caused major Cretaceous/Paleogene episodes of horizontal subduction, beneath S-W United States (Henderson et al., 1984; Liu et al., 2008) and beneath the Central Andes (future Bolivian orocline) (Martinod et al., 2010; O’Driscoll et al., 2012).

Experiments show, however, that ridge subduction only progressively modifies the dip of the slab. The analysis of magmatism in South America suggests that Peruvian and Chilean flat slab segments, indeed, only appeared $\sim 7$ Myrs following the beginning of ridge subduction (Espurt et al., 2008). This delay may explain why the relationship between present-day ridge subduction and the dip of the slab is not straightforward beneath South America. For instance, although the Carnegie ridge is one of the largest ridges subducting beneath this continent, the corresponding slab dip is still close to $30^{\circ}$ (Guillier et al., 2001). The broadening of the volcanic arc in Ecuador (Bourdon et al., 2003) suggests that slab flattening, although being active, is not achieved simply because ridge subduction is too recent there ( $\sim 1$ Myr-old according to Lonsdale and Klitgord, 1978).

The appearance of horizontal slab segments following the subduction of buoyant ridges suggests that experiments in which lateral boundary conditions impose a convergence velocity between the subducting and overriding plates better simulate subduction beneath South America. Indeed, the trenchward advance of South America seems to be related with the opening of the Atlantic Ocean and the motion of the African plate (Silver et al., 1998). However, the analysis of deep seismicity and tomographic data shows that the dip of the Nazca slab is greater than elsewhere at large depths east of flat slab segments (Cahill and Isacks, 1992; Gutscher et al., 2000). Slab steepening located beneath buoyant ridge subduction zones have been observed in free subduction experiments (Martinod et al., 2005). In these experiments, slab steepening is accompanied by a diminution of the subduction velocity resulting from the smaller slab pull force. Martinod et al. (2010) remark that the convergence velocity between the Nazca/Farallon oceanic plate and South America seems to decrease when horizontal slab segments are present beneath the continental plate. In particular, the convergence velocity decreased from $\sim 15 \mathrm{~cm} / \mathrm{yr}$ in the Early Miocene to less than $7 \mathrm{~cm} / \mathrm{yr}$ today (Somoza and Ghidella, 2012). Although several other phenomena such as the uplift of the Central Andes (Iaffaldano et al., 2006) or slab 
interaction with the base of the upper mantle (Quinteros and Sobolev, 2013) may explain this velocity decrease, the trenchward velocity of the Nazca plate probably diminished in response to the smaller slab pull force and higher interplate friction resulting from the subduction of buoyant ridges and from the appearance of flat slab segments. Then, East Pacific subduction zones may represent an intermediate situation between free subduction experiments and models in which the convergence velocity is strictly imposed by lateral boundary conditions, which may explain why ridge subduction both result in the appearance of flat slab segments, in slab steepening east of the horizontal slab segments, and in a decrease of the oceanic plate trenchward velocity.

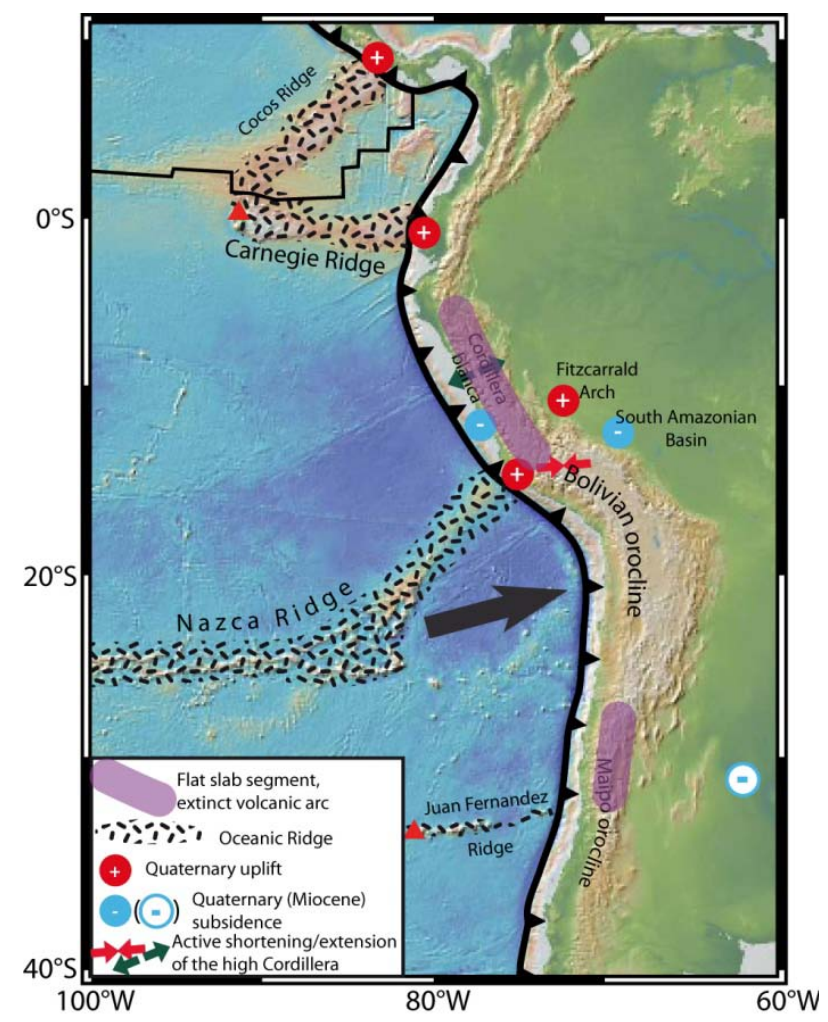

Figure 16: Subduction of oceanic ridges beneath South America. The black arrow shows the $N 75^{\circ} \mathrm{E}$ motion of the Nazca plate with respect to South America. The two major flatslab segments, beneath Peru and North-central Chile, may result from the subduction of the Nazca and Juan Fernandez ridges, respectively. We report fore-arc and back-arc uplift and subsidence attributed to the subduction of oceanic ridges. Shortening in the high Cordillera in front of the locus of subduction of the Nazcca Ridge, and extension in the Cordillera Blanca, have been located.

In contrast, in the Western Pacific, Rosenbaum and Mo (2011) note that there is no obvious correlation between the subduction of high bathymetric reliefs and the dip of the slab. These authors even note that some Western Pacific ridges rather correspond to slabs that are steeper than laterally. Here, we model subducting ridges that are positively buoyant, and that subduct beneath an overriding plate that is advancing toward the trench. This configuration rather corresponds to East Pacific ridges, suggesting that slab flattening of the slab dip angle may not only result from the subduction of buoyant material, but should also involve additional parameters: trench migration velocity, young oceanic plate. This observation confirms the idea proposed by van Hunen et al. (2002) that horizontal subduction zones require both the subduction of a buoyant slab segment and an overriding plate that advances toward the trench.

The observation that West Pacific ridges result in steeper slabs, however, must be considered with care and should take into account ridge obliquity with respect to the trench. For instance, the subduction of the Louisville Ridge beneath the Tonga-Kermadec island arc is marked by a steep slab ( $\left.58^{\circ}\right)$ at $26^{\circ} \mathrm{S}$, where the ridge is now subducting (Bonnardot et al., 2007). At $23^{\circ} \mathrm{S}$, the dip of the slab is slightly smaller $\left(52^{\circ}\right)$, and the dip increases again to the north $\left(60^{\circ}\right.$ at $\left.17^{\circ} \mathrm{S}\right)$ (Figure 17$)$. The smaller slab dip at $23^{\circ} \mathrm{S}$ corresponds to the subduction of the Louisville Ridge at depth, which suggests that ridge subduction may flatten the slab in West Pacific subduction zones too. 


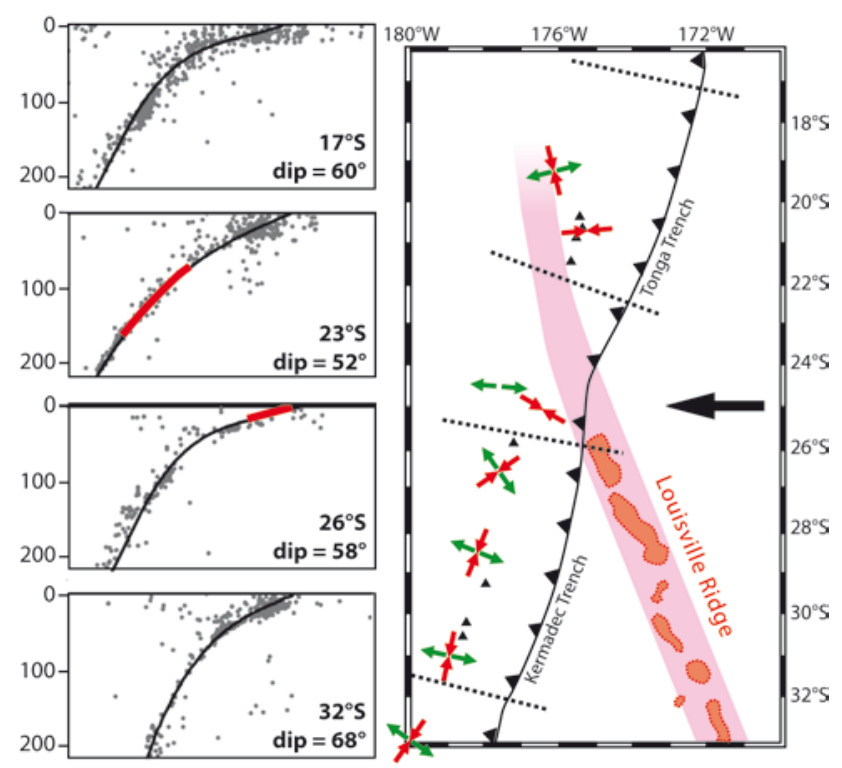

Figure 17: Subduction of the Louisville Ridge beneath the Tonga-Kermadec arc and deformation of the overriding plate. The black arrow shows the convergence azimuth between the Pacific and Australian plates. The four cross-sections presenting the geometry of the WadatiBenioff zone, and the stress-tensors in the overriding plate are from Bonnardot et al. (2007). The supposed subducted segment of the Louisville Ridge has been reported in red in cross-sections at 23 and $26^{\circ} \mathrm{S}$.

Steeper slabs corresponding to ridge subduction may be reconciled with experimental results: (1) if the steep slab segment is located below the subducting buoyant ridge; (2) if the buoyant ridge is large enough to diminish the convergence velocity which, in turn, favors slab steepening. Another possible explanation for the difference between experimental results and observations in the Western Pacific area is that the transformation of oceanic crust into eclogite is rapid enough to erase the ridge buoyancy, which obviously cannot be modeled in analogue experiments.

\subsubsection{Indentation of the overriding plate during ridge subduction}

Rosenbaum and Mo (2011) remark that arc curvature resulting from the subduction of bathymetric reliefs is generally smaller for subduction zones in which the trench advances towards the oceanic plate, as for example in South America. This observation agrees with our experimental results: We note that indentation is smaller when the imposed convergence velocity is rapid (Figure 8) and when the dip of the slab beneath the overriding plate is moderate.

Trench-perpendicular shortening of the overriding plate has been observed in many natural examples. For instance, the subduction of the Louisville Ridge in the Tonga-Kermadec subduction zone is marked by trench-perpendicular shortening of the overriding Australian plate, contrasting with trenchparallel extension prevailing both north and south of the locus of ridge subduction (Bonnardot et al., 2007) (Figure 17).

Subduction of the d'Entrecasteaux Ridge beneath Vanuatu pushes the central Vanuatu segment eastward relative to adjacent arc segments (Taylor et al., 1995). Indentation is accommodated there by trench-perpendicular strike-slip faults, and by the activation of the Central Vanuatu back-arc thrust belt that is now accommodating more shortening than the subduction zone itself does (Lagabrielle et al., 2003).

Indentation may also be accommodated by tectonic rotations on both sides of the ridge, as observed for instance in the Andes. The Juan Fernandez ridge is subducting for $\sim 10$ Myrs at $33^{\circ} \mathrm{S}$ beneath South America (Yañez et al., 2001), and Arriagada et al. (2010) propose that the subduction of this ridge results in the formation of a small orocline (the Maipo orocline, Figure 16) whose appearance during the Neogene has been registered by paleomagnetic data. It has also been proposed that the major rotations accompanying the formation of the Bolivian orocline in the Eocene-Oligocene (Roperch et al., 2006; Arriagada et al., 2008) resulted from the subduction of an oceanic ridge that triggered the appearance of a flat-slab segment beneath the central Andes (James and Sacks, 1999; Martinod et al., 2010). 
The Nazca ridge being oblique with respect to the convergence velocity between the Nazca and South America plates, its locus of subduction is progressively migrating southward with time. Then, the trench does not present any cusp geometry associated with this ridge. Nevertheless, in the Central Peru, counterclockwise rotations younger than 8 Ma migrating to the south have been reported by Rousse et al. (2003) north of the locus of subduction of the Nazca Ridge. We propose that these rotations register the indentation of South America by the Nazca Ridge.

The indentation velocities we observe in analogue models are always smaller than $10 \%$ of the subduction velocity. The comparison with experiment 11 that does not include any overriding plate, and in which the trench geometry modifies much more quickly, shows that the overriding plate rigidity opposes rapid indentation in this experimental set. Natural examples evidence that the indentation of the overriding plate by a subducting oceanic ridge may be very rapid: the indentation rate is larger than half the convergence rate between the subducting and overriding plates in Central Vanuatu (Lagabrielle et al., 2003). In the Maipo orocline, Arriagada et al. report post-10Ma clockwise rotations between the locus of ridge subduction and $\sim 38^{\circ} \mathrm{S}$, which may account for more than $70 \mathrm{~km}$ of differential shortening ( $\sim 10 \%$ of the convergence accommodated between the subducting plate and South America). Arriagada et al. (2008) show that $400 \mathrm{~km}$ of shortening concentrated in the Bolivian orocline is required to explain fore-arc rotations that occurred between 45 and 25 Ma on both sides of the Arica bend. This may represent $25 \%$ of the convergence that occurred between the Farallon plate and South America during this period (Somoza and Ghidella, 2012). These observations suggest that the overriding plate rigidity does not oppose indentation as firmly as in our experiments, and that the rigidity of the overriding plate may have been further decreased to better describe some examples of ridge subduction.

Indentation of the overriding plate is accommodated by larger trench-perpendicular shortening in front of the ridge. This shortening concentrates in the arc and back-arc region close to the trench when the dip of the slab is large, as observed above the Louisville Ridge subduction zone. Experiments also show that shortening may propagate very far from the trench, especially in case a horizontal slab segments appears. The migration of shortening accompanying slab flattening has been clearly described in several examples in North and South America. In NW Argentina for instance, Ramos et al. (2002) describe the inland migration of shortening accompanying Mio-Pliocene migration of volcanism resulting from slab flattening.

\subsubsection{Overriding plate topography}

Finally, ridge subduction may also uplift the overriding plate. Part of this uplift may result from tectonics associated with the indentation of the overriding plate, tectonic shortening in front of the ridge increasing crustal thickness and, in turn, resulting in surface uplift. Experiments also show, however, that part of the surface uplift may also result from flexural effects and dynamic processes related with the descent of the slab within the mantle.

Experiments show that ridge subduction first uplifts the fore-arc area, close to the trench. Fore-arc uplift has largely been described in natural examples, e.g., coastal uplift in Ecuador resulting from the subduction of the Carnegie Ridge (Pedoja et al., 2006) (Figure 16), or in Vanuatu resulting from the subduction of the d'Entrecastaux Ridge (Meffre and Crawford, 2001). In Peru, coastal uplift has also been described above the subducting Nazca Ridge (e.g., Macharé and Ortlieb, 1992). In fact, Regard et al. (2010) suggest that most of the Central Andes coastal area between $30^{\circ} \mathrm{S}$ and $15^{\circ} \mathrm{S}$ has been uplifting during the Pleistocene, and this generalized uplift cannot be attributed to the subduction of topographic anomalies of the oceanic plate. Saillard et al. (2011), however, show that the southward migration of the Nazca Ridge subduction beneath South America is accompanied by the migration of the uplifted segment of the fore-arc. They estimate that the influence of the Nazca Ridge may account for $\sim 0.4$ $\mathrm{mm} / \mathrm{yr}$ uplift south of the Ridge. Le Roux et al. (2000) describe Late Miocene coastal uplift in Lima, 
associated with ridge subduction beneath this region at that time, followed by coastal subsidence as soon as the ridge moved to the south.

Experiments also suggest that fore-arc uplift may be accompanied by some subsidence of the overriding plate in the arc and back-arc area. In contrast, the uplifted area may propagate farther in the overriding plate interiors in case a horizontal subduction zone appears following ridge subduction. Davila et al. (2010) present a detailed analysis of vertical displacements affecting the Argentine Pampas in front of the horizontal slab segment located beneath north-west Argentina. Miocene marine strata mark a long wavelength trench-perpendicular subsidence of the Argentine Pampas, East of the presentday Sierras Pampeanas. Davila et al. (2010) propose that this subsidence resulted from the incipient subduction of the Juan Fernandez Ridge and slab flattening at that time (Figure 16). Afterwards, the appearance of Sierras Pampeanas east of the main Cordillera resulted from the rapid eastward migration of the thrust front, accompanying the growth of the flat slab segment (Ramos et al., 2002).

The Nazca Ridge also impacts the morphology of the Andean Cordillera and back-arc basins located in the western Amazonia in Peru. Lamb et al. (2003) remark that Quaternary tectonics in the highest parts of the Cordillera generally correspond to strike-slip faulting, except at $\sim 15^{\circ} \mathrm{S}$, where shortening is occurring close to where the Nazca Ridge is being subducted. In contrast, at $10^{\circ} \mathrm{S}$ in the Cordillera Blanca, trench-parallel normal faulting is active since the late Miocene (Giovanni et al., 2010), i.e. following the migration of the Nazca Ridge south of the corresponding latitude (Hampel, 2002). Giovanni et al. (2010) note that normal faulting initiated in the Cordillera Blanca afterwards this part of the chain reached its maximum elevation.

Meanwhile, in front of the Peruvian Andes, the South Amazonian Basin is rapidly subsiding (see Figure 16). This basin, indeed, is located $\mathrm{N} 75^{\circ} \mathrm{E}$ (the convergence azimuth) of the present-day locus of subduction of the Nazca Ridge. In contrast, the Fitzcarrald arch, located to the north of this basin corresponds to a segment of the Andean foreland that is uplifting in front of the Nazca Ridge (Rasanen et al., 1987; Espurt et al., 2007). North of the Fitzcarrald Arch, the North Amazonian Basin is also subsiding. In fact, the overriding plate topography resulting from oblique ridge subduction in experiment 8 (Figure 12) fits the present-day dynamics of the Peruvian Amazonia.

\section{Conclusion}

Analogue models confirm that bathymetric reliefs of the subducting lithosphere may affect both the dynamics and geometry of the slab and the deformation of the overriding plate. In this experimental set, we considered that the convergence velocity is imposed by lateral boundary conditions and that ridge subduction does not affect this parameter. This experimental setup rather corresponds to the convergence of large oceanic plates in which the subduction of a bathymetric relief only marginally modifies the force balance that controls plate motion. Experiments suggest that ridge subduction results in slab flattening, possibly leading to the appearance of a horizontal slab segment. This change in the dip of the slab is accompanied by the indentation of the overriding plate by the ridge resulting in arc curvature. Experiments suggest that indentation is larger for small convergence velocity and large slab dip. Finally, experiments show that the subduction of bathymetric reliefs may uplift the overriding plate in the fore-arc area, but also far from the trench in case a horizontal slab segment is forming.

Acknowledgments: This project has been financed by INSU-CNRS (Institut National des Sciences de l'Univers - Centre National de la Recherche Scientifique, France). Analog models have been performed in the Laboratory of Experimental Tectonics (LET) of University ' Roma TRE'. Y. Lagabrielle and N. Kukowski are warmly thanked for reviewing and helping us to improve this manuscript. 


\section{References :}

Adam, J., and C. D. Reuther (2000), Crustal dynamics and active fault mechanics during subduction erosion. Application of frictional wedge analysis on to the North Chilean Forearc, Tectonophysics, 321, 297-325.

Arriagada, C., P. Roperch, and C. Mpodozis (2010), Tectonic rotations in central Chile: The Vallenar and Maipo oroclines, Eos Trans. AGU.

Arriagada, C., P. Roperch, C. Mpodozis, and P. R. Cobbold (2008), Paleogene building of the Bolivian Orocline: Tectonic restoration of the central Andes in 2-D map view, Tectonics, 27.

Bellahsen, N., C. Faccenna, and F. Funiciello (2005), Dynamics of subduction and plate motion in laboratory experiments: Insights into the "plate tectonics" behavior of the Earth, Journal of Geophysical Research-Solid Earth, 110(B1).

Bonnardot, M. A., M. R. E. Ruellan, C. Christova, and E. Tric (2007), Seismicity and state of stress within the overriding plate of the Tonga-Kermadec subduction zone, Tectonics, 26.

Bourdon, E., J. P. Eissen, M. A. Gutscher, M. Monzier, M. L. Hall, and J. Cotten (2003), Magmatic response to early aseismic ridge subduction: the Ecuadorian margin case (South America), Earth and Planetary Science Letters, 205(3-4), 123-138.

Cahill, T., and B. L. Isacks (1992), Seismicity and Shape of the Subducted Nazca Plate, Journal of Geophysical Research-Solid Earth, 97(B12), 17503-17529.

Christensen, U. R. (1996), The influence of trench migration on slab penetration into the lower mantle, Earth and Planetary Science Letters, 140, 27-39.

Cloos, M. (1993), Lithospheric buoyancy and collisional orogenesis - Subduction of oceanic plateaus, continental margins, island arcs, spreading ridges, and seamounts, Geological Society of America Bulletin, 105(6), 715737.

Cross, T. A., and R. H. Pilger (1982), Controls of Subduction Geometry, Location of Magmatic Arcs, and Tectonics of Arc and Back-Arc Regions, Geological Society of America Bulletin, 93, 545-562.

Davies, G. F. (1995), Penetration of Plates and Plumes through the Mantle Transition Zone, Earth and Planetary Science Letters, 133, 507-516.

Davila, F. M., C. Lithgow-Bertelloni, and M. Gimenez (2010), Tectonic and dynamic controls on the topography and subsidence of the Argentine Pampas: The role of the flat slab, Earth and Planetary Science Letters, 295, $187-194$.

Davy, P., and P. R. Cobbold (1991), Experiments on Shortening of a 4-Layer Model of the Continental Lithosphere, Tectonophysics, 188, 1-25.

Dumont, J. F. (1996), Neotectonics of the Subandes-Brazilian craton boundary using geomorphological data: The Maranon and Beni basins, Tectonophysics, 259, 137-151.

Espurt, N., P. Baby, S. Brusset, M. Roddaz, W. Hermoza, V. Regard, P. O. Antoine, R. Salas-Gismondi, and R. Bolanos (2007), How does the Nazca Ridge subduction influence the modern Amazonian foreland basin?, Geology, 35, 515-518.

Espurt, N., F. Funiciello, J. Martinod, B. Guillaume, V. Regard, C. Faccenna, and S. Brusset (2008), Flat subduction dynamics and deformation of the South American plate: Insights from analog modeling, Tectonics, 27.

Funiciello, F., C. Faccenna, and D. Giardini (2004), Role of lateral mantle flow in the evolution of subduction systems: insights from laboratory experiments, Geophysical Journal International, 157, 1393-1406.

Funiciello, F., C. Faccenna, D. Giardini, and K. Regenauer-Lieb (2003), Dynamics of retreating slabs: 2. Insights from three-dimensional laboratory experiments, Journal of Geophysical Research-Solid Earth, 108.

Gerya, T. V., D. Fossati, C. Cantieni, and D. Seward (2009), Dynamic effects of aseismic ridge subduction: numerical modelling, European Journal of Mineralogy, 21, 649-661.

Giovanni, M. K., B. K. Horton, C. N. Garzione, B. McNulty, and M. Grove (2010), Extensional basin evolution in the Cordillera Blanca, Peru: Stratigraphic and isotopic records of detachment faulting and orogenic collapse in the Andean hinterland, Tectonics, 29.

Guillier, B., J. L. Chatelain, E. Jaillard, H. Yepes, G. Poupinet, and J. F. Fels (2001), Seismological evidence on the geometry of the orogenic system in central-northern Ecuador (South America), Geophysical Research Letters, 28(19), 3749-3752.

Guillou-Frottier, L., J. Buttles, and P. Olson (1995), Laboratory Experiments on the Structure of Subducted Lithosphere, Earth and Planetary Science Letters, 133, 19-34.

Gutscher, M. A. (2002), Andean subduction styles and their effect on thermal structure and interplate coupling, Journal of South American Earth Sciences, 15, 3-10.

Gutscher, M. A., J. L. Olivet, D. Aslanian, J. P. Eissen, and R. Maury (1999), The "lost Inca Plateau": cause of flat subduction beneath Peru?, Earth and Planetary Science Letters, 171, 335-341.

Gutscher, M. A., W. Spakman, H. Bijwaard, and E. R. Engdahl (2000), Geodynamics of flat subduction: Seismicity and tomographic constraints from the Andean margin, Tectonics, 19, 814-833. 
Hampel, A. (2002), The migration history of the Nazca Ridge along the Peruvian active margin: a re-evaluation, Earth and Planetary Science Letters, 203, 665-679.

Henderson, L. J., R. G. Gordon, and D. C. Engebretson (1984), Mesozoic Aseismic Ridges on the Farallon Plate and Southward Migration of Shallow Subduction During the Laramide Orogeny, Tectonics, 3(2), 121-132.

Husson, L., B. Guillaume, F. Funiciello, C. Faccenna, and R. L.H. (2012), Unraveling topography around subduction zones from laboratory models, Tectonophysics, 526-529, 5-15.

Iaffaldano, G., H. P. Bunge, and T. H. Dixon (2006), Feedback between mountain belt growth and plate convergence, Geology, 34(10), 893-896.

James, D. E., and I. S. Sacks (1999), Cenozoic formation of the central Andes: A geophysical perspective, in Geology and Ore Deposits of the Central Andes, edited by B. J. Skinner, pp. 1-26, Soc. Econ. Geol., Littletown.

Lagabrielle, Y., B. Pelletier, G. Cabioch, M. Regnier, and S. Calmant (2003), Coseismic and long-term vertical displacement due to back arc shortening, central Vanuatu: Offshore and onshore data following the M-w 7.5, 26 November 1999 Ambrym earthquake, Journal of Geophysical Research-Solid Earth, 108(B11).

Lallemand, S., A. Heuret, and D. Boutelier (2005), On the relationships between slab dip, back-arc stress, upper plate absolute motion, and crustal nature in subduction zones, Geochemistry Geophysics Geosystems, 6.

Lallemand, S. E., J. Malavieille, and S. Calassou (1992), Effects of Oceanic Ridge Subduction on Accretionary Wedges - Experimental Modeling and Marine Observations, Tectonics, 11, 1301-1313.

Lamb, S., Davis, P., 2003. Cenozoic climate change as a possible cause for the rise of the Andes, Nature, 425, 792-797.

le Roux, J. P., C. T. Correa, and F. Alayza (2000), Sedimentology of the Rimac-Chillon alluvial fan at Lime, Peru, as related to Plio-Pleistocene sea-level changes, glacial cycles and tectonics, Journal of South American Earth Sciences, 13(6), 499-510.

Li, Z. H., Z. Q. Xu, and T. V. Gerya (2011), Flat versus steep subduction: Contrasting modes for the formation and exhumation of high- to ultrahigh-pressure rocks in continental collision zones, Earth and Planetary Science Letters, 301, 65-77.

Liu, L. J., S. Spasojevic, and M. Gurnis (2008), Reconstructing Farallon Plate Subduction Beneath North America Back to the Late Cretaceous, Science, 322(5903), 934-938.

Lonsdale, P., and K. D. Klitgord (1978), Structure and tectonic history of Eastern Panama Basin, Geological Society of America Bulletin, 89(7), 981-999.

Macharé, J., and L. Ortlieb (1992), Plioquaternary Vertical Motions and the Subduction of the Nazca Ridge, Central Coast of Peru, Tectonophysics, 205, 97-108.

Martinod, J., F. Funiciello, C. Faccenna, S. Labanieh, and V. Regard (2005), Dynamical effects of subducting ridges: insights from 3-D laboratory models, Geophysical Journal International, 163, 1137-1150.

Martinod, J., L. Husson, P. Roperch, B. Guillaume, and N. Espurt (2010), Horizontal subduction zones, convergence velocity and the building of the Andes, Earth and Planetary Science Letters, 299, 299-309.

Mason, W. G., L. Moresi, P. G. Betts, and M. S. Miller (2010), Three-dimensional numerical models of the influence of a buoyant oceanic plateau on subduction zones, Tectonophysics, 483, 71-79.

McCabe, R. (1984), Implications of Paleomagnetic Data on the Collision Related Bending of Island Arcs, Tectonics, 3, 409-428.

McCann, W. R., and R. E. Habermann (1989), Morphologic and Geologic Effects of the Subduction of Bathymetric Highs, Pure and Applied Geophysics, 129, 41-69.

McGeary, S., A. Nur, and Z. Ben-Avraham (1985), Spatial Gaps in Arc Volcanism - the Effect of Collision or Subduction of Oceanic Plateaus, Tectonophysics, 119, 195-221.

Meffre, S., and A. J. Crawford (2001), Collision tectonics in the New Hebrides arc (Vanuatu), Island Arc, 10(1), 33-50.

Melnick, D., B. Bookhagen, M. R. Strecker, and H. P. Echtler (2009), Segmentation of megathrust rupture zones from fore-arc deformation patterns over hundreds to millions of years, Arauco peninsula, Chile, Journal of Geophysical Research-Solid Earth, 114.

Nur, A., and Z. Ben-Avraham (1981), Volcanic Gaps and the Consumption of Aseismic Ridges in South-America, Geological Society of America Memoirs, 154, 729-740.

O'Driscoll, L. J., M. A. Richards, and E. D. Humphreys (2012), Nazca-South America interactions and the late Eocene-late Oligocene flat-slab episode in the Central Andes, Tectonics, 31.

Pardo, M., D. Comte, and T. Monfret (2002), Seismotectonic and stress distribution in the central Chile subduction zone, Journal of South American Earth Sciences, 15(1), 11-22.

Pedoja, K., L. Ortheb, J. F. Dumont, M. Lamothe, B. Ghaleb, M. Auclair, and B. Labrousse (2006), Quaternary coastal uplift along the Talara Arc (Ecuador, Northern Peru) from new marine terrace data, Marine Geology, 228, 73-91.

Pilger, R. H. (1981), Plate Reconstructions, Aseismic Ridges, and Low-Angle Subduction beneath the Andes, Geological Society of America Bulletin, 92, 448-456. 
Quinteros, J., and S. V. Sobolev (2013), Why has the Nazca plate slowed down since the Neogene?, Geology, 41, 31-34.

Ramos, V. A., E. O. Cristallini, and D. J. Perez (2002), The Pampean flat-slab of the Central Andes, Journal of South American Earth Sciences, 15, 59-78.

Rasanen, M. E., J. S. Salo, and R. J. Kalliola (1987), Fluvial Perturbance in the Western Amazon Basin Regulation by Long-Term Sub-Andean Tectonics, Science, 238, 1398-1401.

Regard, V., R. Lagnous, N. Espurt, J. Darrozes, P. Baby, M. Roddaz, Y. Calderon, and W. Hermoza (2009), Geomorphic evidence for recent uplift of the Fitzcarrald Arch (Peru): A response to the Nazca Ridge subduction, Geomorphology, 107(3-4), 107-117.

Regard, V., M. Saillard, J. Martinod, L. Audin, S. Carretier, K. Pedoja, R. Riquelme, P. Paredes, and G. Hérail (2010), Renewed uplift of the Central Andes Forearc revealed by coastal evolution during the Quaternary, Earth and Planetary Science Letters, 297(1-2), 199-210.

Roperch, P., T. Sempere, O. Macedo, C. Arriagada, M. Fornari, C. Tapia, M. Garcia, and C. Laj (2006), Counterclockwise rotation of late Eocene-Oligocene fore-arc deposits in southern Peru and its significance for oroclinal bending in the central Andes, Tectonics, 25.

Rosenbaum, G., and W. Mo (2011), Tectonic and magmatic responses to the subduction of high bathymetric relief, Gondwana Research, 19, 571-582.

Rousse, S., S. Gilder, D. Farber, B. McNulty, P. Patriat, V. Torres, and T. Sempere (2003), Paleomagnetic tracking of mountain building in the Peruvian Andes since $10 \mathrm{Ma}$, Tectonics, 22.

Saillard, M., S. R. Hall, L. Audin, D. L. Farber, V. Regard, and G. Hérail (2011), Andean coastal uplift and active tectonics in southern Peru: Be-10 surface exposure dating of differentially uplifted marine terrace sequences (San Juan de Marcona, similar to 15.4 degrees S), Geomorphology, 128(3-4), 178-190.

Silver, P. G., R. M. Russo, and C. Lithgow-Bertelloni (1998), Coupling of South American and African Plate motion and Plate deformation, Science, 279(5347), 60-63.

Somoza, R., and M. E. Ghidella (2012), Late Cretaceous to recent plate motions in western South America revisited, Earth and Planetary Science Letters, 331, 152-163.Sparkes, R., F. Tilmann, N. Hovius, and J. Hillier (2010), Subducted seafloor relief stops rupture in South American great earthquakes: Implications for rupture behaviour in the 2010 Maule, Chile earthquake, Earth and Planetary Science Letters, 298, 89-94.

Taylor, F. W., M. G. Baevis, B. E. Schutz, D. Kuang, J. Recy, S. Calmant, D. Charley, M. Regnier, B. Perin, M. Jackson, and C. Reichenfeld (1995), Geodetic Measurements of Convergence at the New-Hebrides-Island Arc Indicate Arc Fragmentation Caused by an Impinging Aseismic Ridge, Geology, 23, 1011-1014.

van Hunen, J., A. P. van den Berg, and N. J. Vlaar (2002), The impact of the South-American plate motion and the Nazca Ridge subduction on the flat subduction below South Peru, Geophysical Research Letters, 29.

van Hunen, J., A. P. van den Berg, and N. J. Vlaar (2004), Various mechanisms to induce present-day shallow flat subduction and implications for the younger Earth: a numerical parameter study, Physics of the Earth and Planetary Interiors, 146, 179-194.

Vogt, P. (1973), Subduction of aseismic ridges, Nature, 241, 189.

Vogt, P., A. Lowrie, D. Bracey, and R. Hey (1976), Subduction of asiesmic oceanic ridges: Effects on shape, seismicity and other characteristics f consuming plate boundaries, Geol. Soc. Amer. Spec. Paper, 172.

Watts, A. B. (2001), Isostasy and flexure of the lithosphere, 458 pp., Cambridge University Press.

Weijermars, R., and H. Schmeling (1986), Scaling of Newtonian and Non-Newtonian Fluid-Dynamics without Inertia for Quantitative Modeling of Rock Flow Due to Gravity (Including the Concept of Rheological Similarity), Physics of the Earth and Planetary Interiors, 43, 316-330.

Yañez, G. A., C. R. Ranero, R. von Huene, and J. Diaz (2001), Magnetic anomaly interpretation across the southern central Andes (32 degrees-34 degrees S): The role of the Juan Fernandez Ridge in the late Tertiary evolution of the margin, Journal of Geophysical Research-Solid Earth, 106, 6325-6345. 